\title{
SEMI-STRONG FORM EFFICIENCY OF GOLD MARKET: COLLECTIVE RATIONALISATION AND ISLAMIC CALENDAR ANOMALY
}

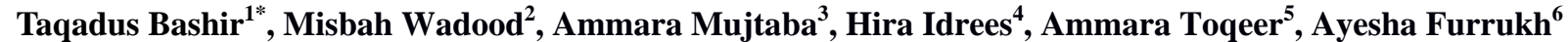

${ }^{1 *}$ Professor, Bahria Business School, Bahria University, Pakistan; ${ }^{2}$ Lecturer Faculty of Management, Department of

Accounting \& Finance, International Islamic University, Pakistan; ${ }^{3}$ Assistant Professor, Bahria Business School, Bahria

University, Pakistan; ${ }^{4}$ Lecturer Bahria Business School, Bahria University, Pakistan; ${ }^{5}$ Assistant Manager, Meezan Bank Ltd, Pakistan; ${ }^{6}$ Statistical Officer, Alpha Centauri Education System, Islamabad, Pakistan.

Email: ${ }^{1 *}$ doc.tbc.tabs@gmail.com, ${ }^{2}$ misbah_wadood@yahoo.com, ${ }^{3}$ ammara_mujtaba@yahoo.com,

${ }^{4}$ hiraidrees90@ hotmail.com, ${ }^{5}$ aiammarasyed@gmail.com, ${ }^{6}$ ayeshafurrukh@ gmail.com

Article History: Received on $23^{\text {rd }}$ March 2021, Revised on $5^{\text {th }}$ April 2021, Published on $9^{\text {th }}$ April 2021

\section{Abstract}

Purpose: The current study aimed to test the impact of two religious months on the return behaviour of the gold market in Pakistan under informational efficiency hypothesis i.e. to empirically test the semi-strong form of EMH in gold market for religious calendar anomaly.

Methodology: Weekly gold prices in rupees per one gram that prevailed in Pakistan for the period January 2007 till December 2015 were selected, summing up to 468 observations. Data was taken from World Gold Council and the Bullionrate database. Event methodology was employed for capturing and analyzing the pre and post event reactions by calculating abnormal returns. Furthermore, average security return variability was employed for robustness check.

Main Findings: Opposing results were achieved for both the lunar calendar occurrences where the gold market is inefficient for the month of Ramazan but is found efficient in Muharram's case concluding into mixed evidence and findings.

Implications/Applications: The contribution of this study differs from previous gold studies in two aspects; first the research investigated the effect of Ramazan and Muharram as Islamic calendar events, and second is that gold market prices of Pakistan that had not been examined earlier. So this study is adding to the literature in the sense of examining the new relationship in Pakistan.

Novelty/Originality of this study: Extensive literature can be found about the global gold market that tested the weak form efficiency, but empirical evidence related to the semi-strong form efficiency of the gold market in Pakistan is not available neither the calendar anomaly related to the gold market is available. The dynamics of this very highly valuable and volatile asset market require investigation of such type.

Keywords: Gold Prices, Currency, Zakat, Ramzan, Muharram, Gold Domestic Demand.

\section{INTRODUCTION}

Throughout history, gold has been valued very high all over the globe and has mesmerized humankind. It had been the standard of exchange and played the role of value storage for various segments of society, including banks and traders, which served as a symbol of social and cultural status and authority due to its ornamental usage. Above that, its scarcity enhanced its value as it is found at $0.0038 \mathrm{ppm}$ (parts per million) or $0.004 \mathrm{~g}$ per earthly tons and is a non-corroding element (Schoenberger, 2011). Wedding ceremonies and dowry in Pakistan and India are incomplete without gold jewellery. In early 2006 gold and copper reserves of two billion tons were found in Balochistan province (i.e. 20 million iotas) (Business Recorder). Irrespective of this amount availability from RekoDiq mines, the country still relies completely on imports from Dubai and is utilised in making jewellery for export purposes, whereas domestic demand is met by recycling existing stuff.

Ranson \& Wainwright (2005) opined that gold is a very good asset shield for multiple other assets since it is different from other assets, is highly liquid in nature, and responds to price variations. Despite the substantial fall in prices of other fundamental minerals, metals, and equities during the financial crisis of 2008, the hike in gold prices was witnessed (Tripathy \& Tripathy, 2016), indicating that people invest in gold during any time and period irrespective of prevalent economic and financial situations due to its significant importance as a liquid asset.

A similar increase in the gold prices was observed during the COVID-19 crisis globally. Yousef \& Shehadeh (2020) investigated the Jordanian Gold market and found that coronavirus increased the volatility of gold returns. They have increased uncertainty about the future of economic \& financial markets, which led to a demand-pull increase in gold prices. Ahmed (2020) reported that due to the pandemic, the investors are inclined. For example, gold was being traded at PKR 104,500 / tola (11.66 grams) and surged to $\$ 1,757$ / ounce (31.10 grams) in the international market and indicated an all-time high. This hike is attributed to three reasons: pandemic (global uncertainty), devaluation of the rupee, and regional impact, 
i.e. border clashes among India and China. This increasing trend of gold prices is expected to continue till some counter vaccine or cure is found to attain global economic stability.

Stability in gold prices indicates a healthy economy, but research history also witnessed that this particular asset market has its peculiar behaviour, and the conventional asset pricing model has been used somehow to understand the gold prices behaviour. (Smith, 2002; Baber, Baber \& Thomas, 2013). Tschoegl (1980), Booth, and Kaen (1979) are among the initial investigators of the global gold market's weak-form efficiency and had contradictory findings for the same market. The first study found efficiency, whereas the second study rejected the random walk hypothesis and concluded it to be inefficient. This debate of predictability of asset prices and market efficiency falls under the purview of Market Efficiency and extensively examined and favoured by Fama (1970; $1965 \& \underline{1998)}$ ). As per the informational market efficiency hypothesis, the consecutive price changes are independent of each other, and one cannot forecast the future price of an asset based on past price trends (Aggarwal \& Sonen, 1998).

The semi-strong form of EMH has always been tested under the purview of behavioural finance macro (BFMA), where the underpinning and processes of groupthink are analysed. The perspective of testing the gold market for the lunar cycle in Pakistan is also built under the percept of groupthink investing in Islamic calendar events as asset markets tend to trend for longer periods and conform to herd mentality. Montier (2010) defined collective rationalisation as a situation where a group ignores warnings about their decisions that might guide them in reassessing their activities and judgements before concluding their decisions. This collective rationalisation has always been interpreted in a negative context that might not be the case of religious-based herd mentality, and the current study aims to explore that as well.

\section{Rationale and Background of Study}

Pakistan is a country that was incepted and gained independence based on two religions and two-nations philosophy. So the lives of the citizens, their behaviours, decisions of all types (economic, social, financial \& investment), thought process, cultural and social events, religious occasions are all heavily influenced by religious values driven from Holy Quran. Weber $\underline{(1930)}$ argued that religious philosophies and practices have a significant impact on the economic growth and development of a country, and this relationship has been ignored in the past by economists. Majeed et al. (2015) adopted event methodology to detect the influence of five Islamic calendar events on Pakistani stock market index returns and found evidence of anomaly existence. The events they selected were three sacred Eid celebrations, Ramazan and Ashoura, and their analysis captured positive but significant abnormal returns in pre-event for all three events. But an investigation of calendar anomaly existence is lacking and awaited in the case of the gold market.

The current study aims to study the influence of two Islamic events, i.e., Ramazan and Aashoura, on the gold prices in Pakistan. Like elsewhere in the world, Muslims in Pakistan observe both these holy events with enormous respect and full confirmation \& compliance. Therefore, these religious events have a significant effect on economic and financial decisions. At the beginning of Ramazan and even before and during this holy month, Muslims pay zakat (act for purification of the wealth) as an obligation towards Allah, and this religious obligation is focused on reducing the gap between haves and havenots, i.e. for the improvement of the financial well-being of underprivileged and for the psychological well-being of privileged ones. In simple words, it is termed an Islamic charity (Ahmad \& Mahmood, 2009; Masroom, Yunus \& Huda, 2020). Zakat is paid on overall wealth, including livestock, general wealth, gold and real estate, etc., same is the case with the month of Aashoura that is observed by conducting several religious rituals and ceremonies. Therefore, at the arrival of both these months of religious importance, the gold and silver markets experience reactions (over-or under-) due to the religious sentiments of the Muslims, with a significant impact on the economy, leading to the assumption that Islamic events are responsible for fluctuation in gold and silver prices. According to Ississ (2010), both events do not have the same impact on the gold returns because Ramazan yielded a positive impact, whereas Aashoura yielded a negative association.

The current study has analysed the reaction in gold market prices during the event, in pre-and post-event windows where the events are months of Ramazan and Muharram. Findings will contribute towards academia, specifically in the literature of event methodology studies, announcement impact studies, calendar anomalies, and semi-strong form of efficiency. In general, results and findings will develop awareness among international stakeholders, i.e. individuals, financial and investment decision-makers as buyers and sellers in gold markets, to improve their future decisions.

Gold prices are a significant major indicator of economic health other than stock markets, and this asset market has its dynamics that need to be explored. Hike and escalation in gold prices indicate an unhealthy market because investors and individuals begin hoarding gold bars as a remedy against currency devaluation. In contrast, a dip in prices shows a healthier economy because the money supply is shifted to other profit reaping investments, e.g., stocks, bonds, real estate, construction, commodity market, etc. Secondly, a gradual increase in gold prices over the number of years benefit greatly long-term investors compared. Hence, testing the semi-strong form of efficiency in the context of Islamic calendar anomalies will be of interest and benefit not only to academicians but also for individuals, investors, financial institutions, policymakers, and asset markets regulators. 


\section{Gap Analysis / Problem Statement}

Pakistan is a Muslim country that came into being in Islam, and here, all religious months and religious events are observed and celebrated with great respect, zeal, and enthusiasm. Furthermore, under such events, demand and supply forces of various asset markets face different reactions like all the other asset markets worldwide in other religions, e.g., Christianity and Hinduism have their religious event dynamics. To comprehend the impact and influence of religious events and sacred rituals is highly significant because their recurrence as per the lunar calendar (rotation/turn of occurrence bringing change in buyers and sellers' routine behaviour and alter the normal market trends of a few specific items and assets. The Islamic events are lunar months and recur according to the lunar calendar but not with solar; therefore, they fall in almost every month of the solar calendar and are not tied up with winter or summer specifically. During the month of Aashura, wedding ceremonies are completely avoided due to the respect and sorrow the Mulsim community express for their religious and spiritual leaders. Therefore, the demand for gold is expected to decline, whereas due to zakat payment at the arrival of Ramazan, again gold prices are expected to face some reaction from the buyers and sellers.

Ississ (2010) investigated and found that religious events are a very important factor behind price behaviour in many asset markets and specifically in the gold market. Extensive literature can be found about a global gold market that tested the weak form efficiency. However, empirical evidence related to the semi-strong form efficiency of the gold market in Pakistan is not available neither the calendar anomaly related to the gold market is available. The dynamics of this very highly valuable and volatile asset market require investigation of such type.

\section{Objectives of the Study}

Under informational efficiency, the study aimed to:

- Empirically test the semi-strong form of EMH in the gold market.

- Examine the religious calendar anomaly in the gold market.

\section{LITERATURE REVIEW}

\section{Efficient Market Hypothesis}

The historically efficient market theory is mostly tested for the stock market, and little evidence can be found for testing the efficiency of derivatives, rice, hog futures, timber \& housing construction market, and those also for only weak-form efficiency. EMH posits that asset prices reveal all relevant, accessible information about the intrinsic value of an asset. A particular financial instrument embodies a right on future cash flows, and therefore the fundamental value of an investment instrument is the present value of those future flows expected to be reaped by the owner. So if the expectations of all investors in the market are the same based on the same level of information, it means that the market is efficient and no one can beat the market (Bashir, Ilyas \& Furrukh, 2011).

The EMH, highly advocated by Fama (1970, 1965), states that stock/asset always trade at their just value, and it is not possible for investors to either buy devalued stock/asset or sell stocks for exaggerated prices, making it difficult for anyone to outperform market via stock experts or market timing technicians. The only way to reap higher possible profits for an investor is a chance occurrence or purchase riskier investments. It further posits three levels of efficiency, namely weakform, semi-strong form, and strong form.

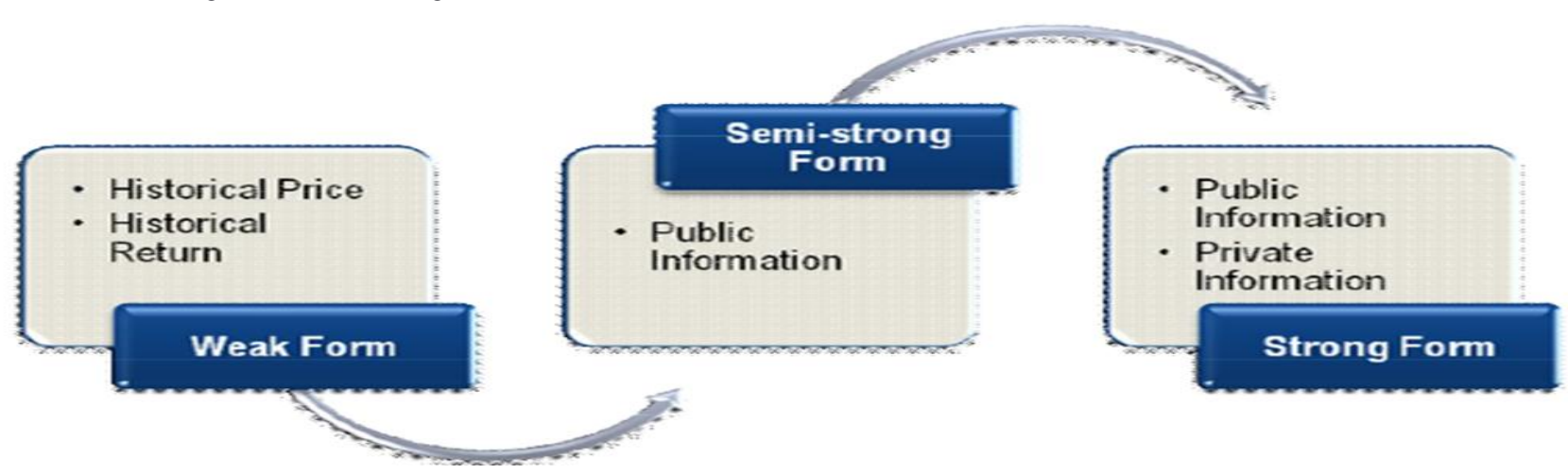

The current study's focus is only a semi-strong form of efficiency, which propounds that whenever there is new public information available in the market about an asset, the asset prices rapidly adjust to it in such a manner that the probability of earning abnormal profits trading them in the market becomes impossible. If the prices change magnitude to some public news is substantial and speedier, consistent ascending or descending adjustment in price after the initial purchase/sale price 
indicates semi-strong for efficiency. This phenomenon's persistence further suggests that investors sought the information in biased ways, hence turning the market inefficient.

Louis Bachelier (1900), a French mathematician, was a pioneer researcher who examined stock market returns in his dissertation, and his remarkable work stated that the possibility of statistical independence in stock returns exhibit that change in today's return is not related to the change in tomorrow's return and this statistical notion of his became the basis of random walk, that later developed inefficient market hypothesis. Until the late 1950s, indiscreetly, this work by Bachelier's remained essentially disregarded and unnoticed. Meanwhile, Williams (1938) became first discovered the possibility of the information on stock prices while investigating their intrinsic value based on the economic fundamentals proposition. Later, Kendall (1953), a British statistician, detected and reported that British stocks' weekly returns were statistically uncorrelated, concluding the non-predictability pattern among them.

The extensive work by Fama in the 1970s was criticised by Grossman \& Stiglitz (1980) that market efficiency is contingent on market friction, cost of security analysis, and trading; otherwise, an extremely high level of efficiency is not reliable internally. Because it will obstruct lucrative opportunities needed to harvest information for stimulation of security investigation and level of efficiency may differ across the market.

\section{Contemporary Criticism on work by Fama}

Semi-strong from efficiency work experienced many inconsistencies later in the 80s and 90s; among them, the most popular were anomalies termed as small-firm effect and January effect. The neo-classical theorists attribute this either to market friction or asset-pricing model misspecifications, e.g., both the above-mentioned effects were considered premiums needed to remunerate small stockholders to be illiquid specifically at the turn of the year. Fama (1998) explained these abnormalities as under-reaction and overreaction that are intermittent and complex and can be termed as chance incidences that are smoothed out during varied periods and when different methodologies are applied identify them. It can be established from the discussion that may the prices take a long to adjust to the information and may display slow moves while exhibiting deviation from fundamentals, but despite these, EMH has significant logical uses. EMH can help detect the asset price change trends and change direction over short time spans like days, weeks, months, etc. In simple words, the variation in the inherent value of equity is met reasonably by reaction in the stock price in response to new information. Furthermore, asset price informational efficiency varies among markets and countries.

\section{Gold Market Overview}

The gold market is the oldest among all the current financial asset markets, and the Bretton Woods gold standard monetary system's termination turned it into a free market somewhere between 1968-1973. Originally this system had a standard unit of exchange determined by a preset amount of gold, i.e., one oz of the gold was equal to $\$ 35 / 12.50$ British Pounds. The UK happens to be the oldest, biggest and most influential, and highly liquid market among the gold markets.

The gold investment market possesses the longest and oldest history among all financial instruments that date back to somewhere around $500 \mathrm{BC}$ when the gold coin was first made. It is an extremely robust market as it presents multiple options to its participants, e.g., storage of wealth, investment, and collateral of high quality (Bhatia, Dempster, \& Stanley, 2011). The major global traders, storage holders, and distributors of physical gold bullion bars are clustered in mature, large, and organised markets consisting of Hong Kong, Singapore, and Switzerland (The Gold Core, 2013).

The gold-based financial instruments consisting of ETFs, Futures, and other derivatives are considered trade-off tools of high frequency, developed by mature and highly developed markets like Brazil, Canada, Japan \& Netherland, united states, etc. on one side and cluster of average size markets consisting of Australia, Belgium, France, Germany, Luxembourg, South Africa \& turkey on the other end. The small size but rapidly growing participants of this market are grouped as China, India, the South Asian bracket, middle east countries (Bahrain, Jordan, Kuwait, KSA, and UAE), and Russia. Minor markets categorised as frontier take-off strugglers consist of Africa and the middle east (Egypt, Kenya, and Israel), Asia-Pacific (Nepal and Pakistan), and Mexico.

\section{Pakistan the gold Reserves}

Pakistan is endowed with massive mineral reserves and possesses the second largest salt mine and coal deposits in the world coupled with the fifth largest gold and copper deposits. These Copper and gold deposits mainly exist in RikoDiq (Baluchistan), discovered in early 2006, and happen to be the world's largest reserves (around 1,656 million tons) with a projected surface estimation of approximately $\$ 100$ billion. The mounting global gold demand is above 2500 tones, and Pakistan's absorption among this is above 100 tones, making Pakistan the $10^{\text {th }}$ largest global gold market as per demand (Nadeem, 2015; Shah, 2018). Figure 1 shows that the gold reserves in Pakistan remained unchanged at 64.50 Tones in 2015 (Q3, Q4) and averaged 64.94 tons (between 2000-2015), achieved a high of 65.44 tons in 2007 (Q4) but a record low of 64.38 tons in 2010. Gold Reserves in Pakistan is stated by the World The gold Council (Shah, 2018). 


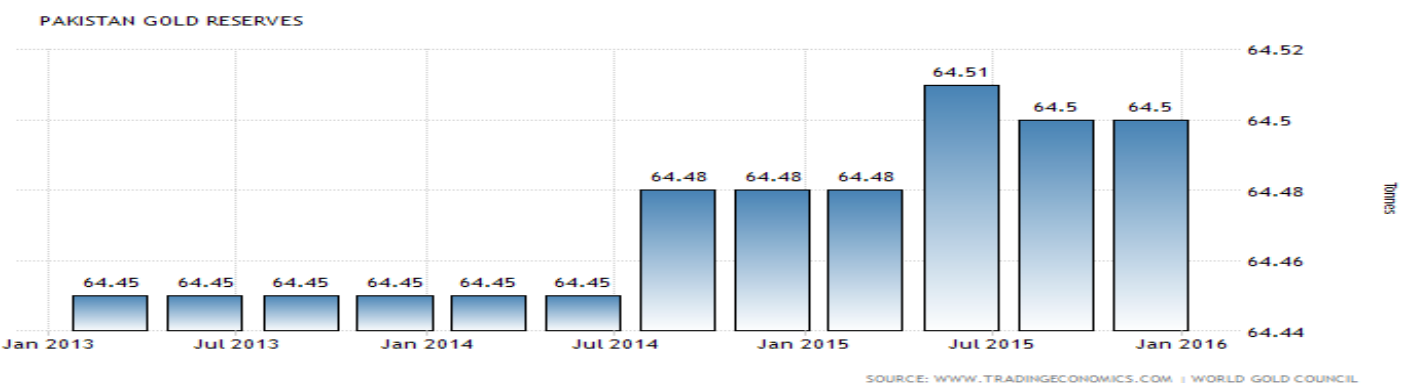

Figure 1: The gold Reserves in Pakistan

Source: Shah, 2018

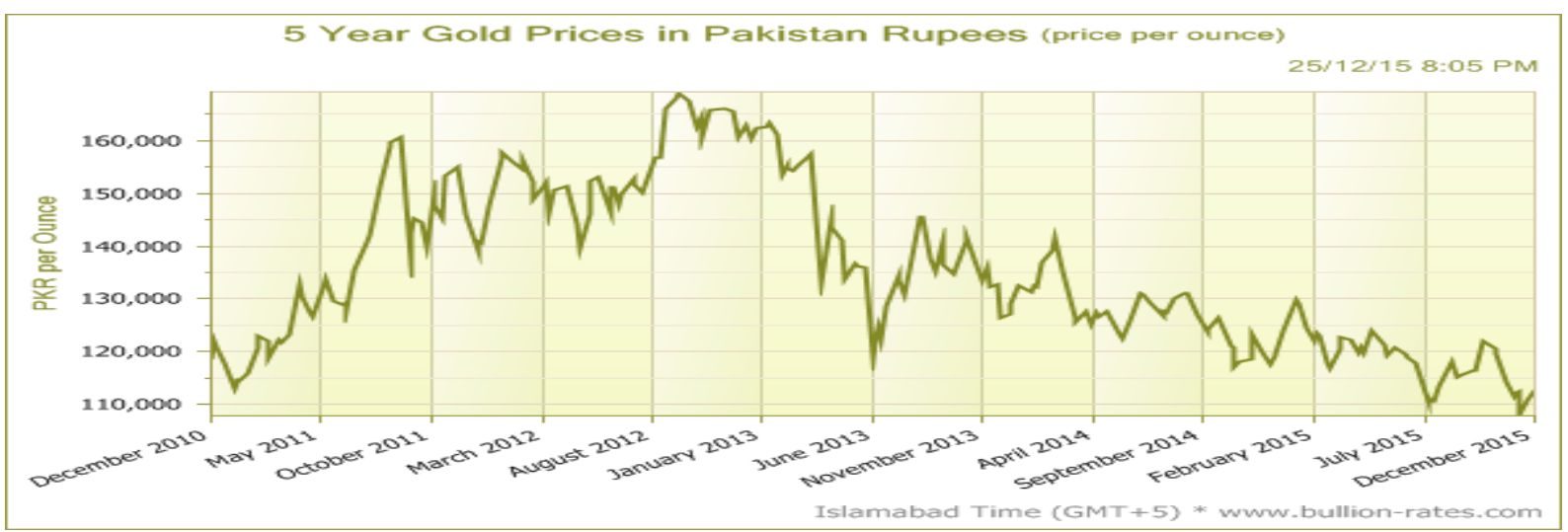

Figure 2: 5 Years the gold Prices in Pakistan

Source: Author Analysis

Table 1: The gold Based Financial Instrument Trading Markets

\begin{tabular}{|c|c|c|c|c|c|}
\hline Country & $\begin{array}{l}\text { Trading } \\
\text { days }\end{array}$ & $\begin{array}{c}\text { Cash/physical } \\
\text { settlement }\end{array}$ & $\begin{array}{c}\text { Contract } \\
\text { size/purity/in.margin }\end{array}$ & Main the gold market(s) & $\begin{array}{l}\text { Main trading } \\
\text { city(ies) }\end{array}$ \\
\hline Australia & Mon-Fri. & Both & $100 \mathrm{oz} / .9995 /$ aud6600 & ASX/SFE & Sydney \\
\hline Bahrain & Mon-Fri. & Cash & $1 \mathrm{~kg} / .995 / \mathrm{bhd} 4 \%$ & BFX & Manama \\
\hline Brazil & Mon-Fri. & Both & $250 \mathrm{~g} / .999 / \mathrm{R} \$$ average & BM\&FBovespa & Rio/Sao Paulo \\
\hline Canada & Sun-Fri. & Both & $100 \mathrm{oz} / .995 / \mathrm{cad} 5 \%$ & CMC/WCE & Toronto/Winn. \\
\hline China & Mon-Fri. & Both & $100 \mathrm{~g} / .9999 / \mathrm{cny} 10500$ & SHFE/SGE & Shanghai/Shenzhen \\
\hline \multirow[t]{2}{*}{ Germany } & Mon-Sun. & Cash & $100 \mathrm{oz} / .9995 /$ euro5\% & EUREX/SOFFEX & Frankfurt \\
\hline & Mon-Sat. & Both & $\begin{array}{l}\text { 100tael/.99/free }-35 \\
\mathrm{~kg},\end{array}$ & 5 CGSE/HKEX/HKMEX & Hong Kong \\
\hline India & Mon-Fri. & Both & $1000 \mathrm{~g} / .995 /$ inr75000 & NCDEX/MCX/NMCE & Calcutta/Mumbai \\
\hline Indonesia & Mon-Fri. & Both & $1 \mathrm{~kg} / .9995 / \mathrm{idr} 15 \%$ & JFX/ICDX & Jakarta \\
\hline$\underline{\text { Japan }}$ & Mon-Fri. & Both & $1 \mathrm{~kg} / .9999 / \mathrm{jpy} 45000$ & TOCOM & Tokyo \\
\hline Malaysia & Mon-Fri. & Cash & $100 \mathrm{~g} / .995 / \mathrm{rm} 4004$ & KLSE/MDEX/KLCE/ & Kuala Lumpur \\
\hline Mexico & Mon-Fri. & Cash & $100 \mathrm{oz} / / .995 / \mathrm{mxn} 10 \%$ & MEXDER/MSE & Mexico City \\
\hline Nepal & Mon-Sat. & Cash & $1000 \mathrm{~g} / .995 / \mathrm{npr} 60000$ & MEX/NSE & Kathmandu \\
\hline$\underline{\text { Pakistan }}$ & Mon-Fri. & Both & $\begin{array}{l}10 \mathrm{z} / .995 / \mathrm{pkr}- \\
\text { formula }\end{array}$ & PMEX/NCEL & Karachi \\
\hline Russia & Mon-Fri. & Cash & $100 \mathrm{~g} / .9999 / \mathrm{rub} 800$ & MOEX/RTS & Moscow \\
\hline \multicolumn{6}{|l|}{ Saudi } \\
\hline Singapore & Mon-Fri. & Cash & $25 \mathrm{~kg} / .9999 / \mathrm{sgd} 10 \%$ & SICOM/SGX/SMX & Singapore \\
\hline South Africa & aMon-Fri. & Cash & $100 \mathrm{~g} / .995 / Z a r 7800$ & JSE-CDM/SAFEX & Johannesburg \\
\hline South Korea & a Mon-Fri. & Cash & $1 \mathrm{~kg} / .9999 / \mathrm{krw} 10000$ & KRX & Busan/Seoul \\
\hline
\end{tabular}




\begin{tabular}{|c|c|c|c|c|c|}
\hline Switzerland & Mon-Fri. & Cash & $100 \mathrm{oz} / .9995 / \mathrm{chf} 5 \%$ & EUREX/SOFFEX & Zurich \\
\hline Taiwan & Mon-Fri. & Cash & $10 \mathrm{oz} / .995 / \mathrm{twd}-\mathrm{mkt}$. & TAIFEX & Taipei \\
\hline Thailand & Mon-Fri. & Both & $152.44 \mathrm{~g} / .965 / \mathrm{thb}-\mathrm{mkt}$ & TFEX/SET & Bangkok \\
\hline Turkey & $\begin{array}{l}\text { Mon- } \\
\text { Sun. }\end{array}$ & Both & $400 \mathrm{oz} / .995 /$ try $15 \%$ & IGE/ISE & Istanbul \\
\hline UAE & Mon-Fri. & Both & 320z/.995/aed10\% & DGCX/DMCC/DCCC & Dubai \\
\hline $\begin{array}{l}\text { UK (Arounc } \\
1800)\end{array}$ & Mon-Fri. & Both & $400 \mathrm{oz} / .995 / \mathrm{gbp} 5 \%$ & LBM/TLGMFL/LSE & London \\
\hline US & $\begin{array}{l}\text { Mon- } \\
\text { Fri./Sun- } \\
\text { Fri. }\end{array}$ & Both & $100 \mathrm{oz} / .995 / \mathrm{usd} 1350$ & \multicolumn{2}{|c|}{ COMEX/CME/GLOBEX/NYMEXNew York/Chicago } \\
\hline Vietnam & - & - & - & - & - \\
\hline
\end{tabular}

Sources: Ntim, English, Nwachukwu, \& Wang, (2015) ${ }^{1}$.

Literature has documented numerous anomalies in stock market returns at various times following the calendar e.g. on a turn of the year, month, week, and day, and around holidays (Thaler, 1987a; 1987b; Jacobs \& Levy, 1988). But scanty evidence can be found on investigating the impact of worldwide observed religious and cultural events as per the lunar or other calendar recurrences.

\section{LITERATURE REVIEW OF ALL FIVE CATEGORIES}

\section{The Mainstream Religious Islamic Events Literature}

Majeed et al. (2015) investigated Pakistan stock market anomaly under the impact of five Islamic calendar events, namely Ramazan, Eid-ul-Fitr, Eid-ul-Adha, Ashora, and Eid-Milad, and employed daily returns from KSE-100 Index for the period 2001-2012. Regression analysis and event methodology revealed a significant impact of Eid Ul Adha on the stock returns and identified significant abnormal returns in the pre-event window for the rest of four events and captured post-event window abnormal returns for Ramadan Eid-ul-Fitar only. Similarly, Husain (1998) and Seyyed, Abraham \& Al-Hajji (2005) investigated the impact of Ramazan on the KSE and Saudi Arabian stock market, respectively, but none focused on the gold market.

Similarly, Ississ (2010) coined the term faith impact and studied the influence of Ramadan and Ashoura on daily returns and trading volumes of 17 financial markets from Muslim countries by using pooled fixed effects panel regression and detected significant drops in both series where return effect was not unidirectional. However, Ramadan yielded a positive impact on daily returns, and Ashoura yielded a negative impact. Whereas Akhter, Sandhu, and Butt (2015) analysed the impact of ZilHijjah on stock returns of six Islamic countries and detected that it has a significant negative impact on the volatility of Turkish, Malaysian, Moroccan, and Egyptian market and no effect for the other two.

On the other hand, Azimi et al. (2012) examined the stock returns of Tehran stock Exchange for the effect of Muharram and Safar months and chose a 6-month window consisting of two months as a pre-event of Muharram and Safar, two months of Muharram and Safar as event and two months as post window. Variance analysis and repetitive measures (RM ANOVA)

\footnotetext{
${ }^{1}$ Australian Securities Exchange (ASX) and Sydney Futures Exchange (SFE) merged in 2006; Shanghai Futures Exchange (SHFE)/Shanghai Gold Exchange (SGE). Brazilian Mercantile and Futures Exchange (BM\&F) and Sao Paulo Stock Exchange (Bovespa) merged in 2008. Chinese Gold and Silver Exchange Society (CGSE) of Hong Kong; DeutcheBorse (DTB), and Swiss Options and Financial Futures Exchange (SOFFEX) merged in 1998 to form EUREX. National Commodity and Derivative Exchange (NCDEX)/Multi Commodity Exchange of India (MCX)/National Multi Commodity Exchange of India (NMCE). Indonesia Commodities and Derivatives Exchange (ICDX)/Jakarta Futures Exchange (JFX). Tokyo Commodity Exchange (TOCOM) via a merger of Tokyo Textile Exchange (1951), Tokyo Rubber Exchange (1952), and Tokyo Gold Exchange (1982) in 1984. Kuala Lumpur Stock Exchange (KLSE)/Malaysian Derivatives Exchange (MDEX) merged with the Kuala Lumpur Options and Financial Futures Exchange (KLOFFEE), and the Commodity and Monetary Exchange of Malaysia (COMMEX) in 2001 to form Bursa Malaysia in 2004. Mexican Derivative Exchange(MEXDER)/Mexican Stock Exchange (MSE). Mercantile Exchange of Nepal (MEX)/Nepal Spot Exchange (NSE). National Commodity Exchange (NCEL), now called Pakistan Mercantile Exchange (PMEX). Russian Trading System (RTS), restructured in 1995 as Moscow Exchange (MOEX). Bahrain Financial Exchange (BFX). Singapore Stock Exchange (SGX)/Singapore Commodity Exchange (SICOM)/Singapore Mercantile Exchange (SMX). JSE Commodity Derivatives Market (JSE-CDM) merged with the South African Futures Exchange (SAFEX) in 2001. Korean Exchange (KRX). Taiwan Futures Exchange (TAIFEX). Thailand Futures Exchange (TFEX)/Stock Exchange of Thailand (SET). Istanbul Gold Exchange (IGE) merged with the Istanbul Stock Exchange (ISE) to form Borsa Istanbul in 2013. Dubai Multi Commodities Centre (DMCC)/Dubai Gold and Commodities Exchange (DGCX)/Dubai Commodities Clearing Corporation (DCCC). Refers to the London morning (AM) and afternoon (PM) gold price fixing by the powerful five members ('quintupoly') of the London Bullion Market Association (LBMA) via The London Gold Market Fixing Ltd (TLGMFL). The current five London Gold Fix Members (LBMA members currently consists of 53 full members and 33 associate members) are: The Bank of Nova ScotiaScotia Mocatta (current chair), Barclays Capital, HSBC Bank USA London Branch; N M Rothschild \& Sons LTD; and Societe Generale. COMEX is the Commodity Exchange division of the New York Mercantile Exchange (NYMEX)/Chicago Mercantile Exchange (CME Group). Egypt, Saudi Arabia and Vietnam to do not have formal gold markets, but do significant trading through the over-the-counter market (i.e., they are amongst the top ten major gold consumer countries in the world), as reported by the World Gold Council (WGC) in March 2014, and thus are included in the sampled countries. All reported trading arrangements are based on information as of March 2014. 'Oz' means troy ounce and 'g' or ' $\mathrm{kg}$ ' is kilogram.
} 
indicated a significant relationship between the stock returns of 175 companies for the period 2006-2010 and the two Islamic months. Similarly, Białkowski, Etebari, Wisniewski (2011) investigated and found that stock returns during Ramazan were significantly high and less volatile than the rest of the year for sample period 1989-2007and suggested its positive impact on investor psychology.

Literature on efficiency testing by using event study methodology;

In an efficient market, all relevant information regarding a firm's stock is reflected in its market price. Lack of consensus among economists and financial analysts regarding market efficiency necessitates the study of EMH. One cogent reason to study market efficiency is the role of stock markets acting as a financial intermediary between the saver and borrower for the distribution of scarce resources via the price mechanism. Bashir et al. (2011) investigated the Weak-Form Efficiency of the Textile Sector of Pakistan by taking daily closing stock prices for individual firm level from June 1997 to April 15, 2009, from twelve high volume trading textile companies Karachi Stock Exchange. Their results refuted the null hypothesis of weak-form Efficient Market Hypothesis in the textile sector and detected exploitable patterns concluding inefficiency.

Konchitchki and O'Leary (2011) explained the importance of event study methodologies in information systems research and investigates event studies in information systems. Other studies that adopted event study methodology to explore the impacts of different events are Bloom (2011), Ahsan, Chowdhury, and Sarkar (2014), Majeed et al. (2015), and Ississ (2015).

A number of factors and events that affect the gold prices have been studied, for example, conventional and religious holidays and events, inflation, oil prices, interest rate, exchange rate, political risk, credit risk default premium, the gold lease rate, stock price, etc. However, the focus of this study is only the two most important events, i.e. Ramazan and Aashoura. This study aims to describe the variation of the domestic gold price by considering the effects of Ramazan and Aashoura so that the factors behind the gold price in Pakistan can be comprehended.

The contribution of this study differs from the contribution of previous gold studies. First of all, this research will consider the effect of Ramazan and Muharram events, and secondly, most are the selection of Pakistan's gold market that has not been examined earlier. So this study is adding to the literature in the sense of examining the new relationship in Pakistan. Secondly most recent and most frequent weekly average data is used in this study with 468 observations.

\section{Research Hypotheses}

H1: Pakistani the gold markets will be semi-strong form efficient w.r.t to Islamic calendar events.

H2: The gold markets will be semi-strong form efficient w.r.t Ramazan.

H3: The gold markets will be semi-strong form efficient w.r.t Aashura.

\section{RESEARCH METHODOLOGY}

Whenever the efficient market hypothesis is tested concerning informational efficiency and an announcement's impact, the most appropriate technique is event methodology. Event studies are considered best because one can analyse the impact of events relevant to a particular asset and the trends in its prices. Conceptually, event methodology analysis captures the difference between normally expected asset returns and the abnormal returns resulting from event, announcement, or recurring activity, for example, calendar events, etc. Thereof various methodical techniques are adopted for segregating abnormal returns as per modelling methods around or before and after the event dates. To study the magnitude and direction of asset price change patterns, this versatile methodology is very useful. For these reasons, event studies are extensively conducted in finance, economics, and marketing and studying the asset market reaction to economy-wide events, e.g. market shocks, regulatory changes, or calamities and disasters. The corporate sector happens, e.g. corporate restructuring, CSR, mergers \& acquisitions, announcements like a bonus, earnings, stock-splits, political, law, or technological change-related events, also generate a reaction in the market price and become a focus of study (MacKinlay, 1997; McWilliams \& Siegel, 1997).

For the current study, weekly the gold prices in rupees per one gram in Pakistan were selected for the period January 2007 till December 2015, summing up to 468 observations. Data was taken from World The gold Council and the Bullion-rate database. For event window, creation dates of Islamic months, Ramazan and Muharram dates are obtained from for the same period where beginning and end dates are included for each study period data set, and abnormal returns are calculated to seize the effect of Islamic month on the gold market (MacKinlay, 1997; McWilliams \& Siegel, 1997; Bloom, 2011; Ahsan, Chowdhury \& Sarkar, 2014; Majeed et al., 2015; Ississ, 2010).

$A R_{g, t}=R_{g, t}-R_{e}$

$\mathbf{R}_{\mathrm{g}, \mathrm{t}}=$ Return of The gold on day $t$

$\boldsymbol{R}_{\boldsymbol{e}}=$ Expected Return 
The gold prices are univariate series where abnormal returns are computed by subtracting expected returns from actual returns after taking a log of current price to the previous price ratio. Then cumulative abnormal returns (CAR) are computed that indicates the extent of market adjustment in response to change in the value of the gold at the arrival of Islamic months. CAR's negative or positive values show investors' response under Islamic event effect resulting in incremental positive or negative future cash flows.

$$
\text { CARt }=\sum_{t=1}^{n} \mathrm{ARg}, \mathrm{t}
$$

\section{Security Returns Variability}

The Asset/Security Returns Variability Model is used to gauge the market's reaction to the event announcements. The model is:

$$
\underset{\mathbf{S R}}{\mathbf{S}(\mathbf{A R})} \underline{\mathbf{A R}}^{\mathbf{2}}{ }_{\mathrm{i}, \mathrm{t}} .
$$

Where

$\mathrm{SRV}_{\mathrm{i}, \mathrm{t}}=$ Security Returns Variability for security $\boldsymbol{i}$ at time $\boldsymbol{t}$

$\mathrm{AR}^{2}{ }_{\mathrm{i}, \mathrm{t}}=$ Abnormal returns for security $\boldsymbol{i}$ at time $\boldsymbol{t}$

$\mathrm{V}(\mathrm{AR})=$ Variance of the abnormal returns.

\section{Average Security Returns Variability}

The Average Security Returns Variability (ASRV) is calculated by averaging all the SRVi,t for all the event weeks. The equation is:

$$
\operatorname{ASRV}_{\mathbf{t}}=\operatorname{SRV}_{\mathrm{i}, \mathrm{t}} *(\mathbf{1} / \mathbf{n})
$$

Where,

$$
\begin{aligned}
& \operatorname{ASRV}_{\mathrm{t}}=\text { Average Security Returns Variability at time } t \\
& \mathrm{SRV}_{\mathrm{i}, \mathrm{t}}=\text { Security Returns Variability for security } \boldsymbol{i} \text { at time } \boldsymbol{t} \\
& \mathrm{n}=\text { Number of event weeks in the particular event window }
\end{aligned}
$$

\section{T-Test}

The significance of the reaction in the asset prices (ASRVt) is tested by using the T- statistics as follows:

$$
t_{\text {stat }}=(A S R V-1) \times \sqrt{n} / s
$$

Where $\boldsymbol{n}$ is the number of event weeks in the sample and $\boldsymbol{s}$ is the Standard Deviation of abnormal returns.

\section{RESULTS AND DISCUSSION}

To test the semi-strong form of the gold market efficiency data for a complete month of Ramazan and the first 10 days of Muharram are taken for sample for the period 2008-2015. Weekly averages of the gold prices are taken for making it 52 observations per year, and the event dates differ per solar year due to the lunar cycle being followed.

The event window for Ramazan comprises 40 weeks, whereas the Aashura event comprises 18 weeks centered as event weeks, respectively. For Ramazan, 5 weeks before are pre-event window, 4 (somewhere 5 weeks) are event weeks, and 5 weeks after is the post-event window. In the case of Ashura 3 weeks before is pre-event, 2 event weeks are of Aashura, and 3 weeks after events week comprises post-event window. 


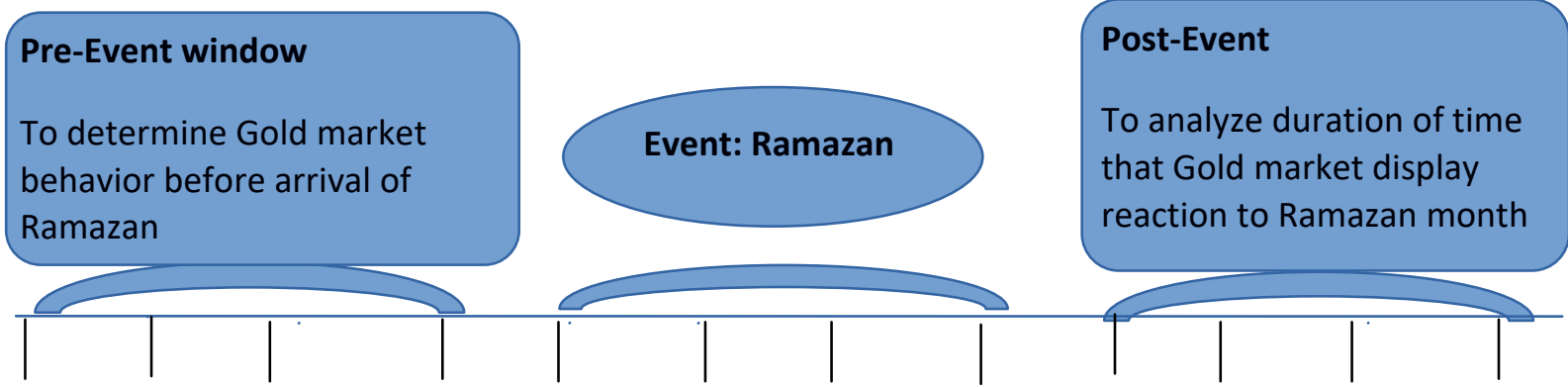

\section{PrR4 PrR3 PrR2 PrR1 R1 R2 R3 R4 PoR1 PoR2 PoR3 PoR4}

Where, R=Ramazan Event,

PrR= Pre-Event Reaction and PoR=Post-Event Reaction

\section{Ramazan Results and Analysis}

The second form of EMH assumes that announcement impacts prove market cycle pattern, and Semi-strong form tests are used to evaluate the pace of price changes to publicly available information. With the arrival of capitalistic thoughts, the influence of an economic, political, or social event will be merged into the asset prices in due course of time. This led to the emergence of event study methodology, a general statistical technique in business research to determine the impact of an event. As per McWilliams and Siegel (1997), an event study methodology "governs whether there is an 'abnormal' stock price effect related to an anticipated or unanticipated event. From this examination, the researcher can infer the implication of the event".

So in a way, the behaviour of the market in response to an event is needed to be studied. Like various events, Ramazan and Aashura are two significantly important events moving Muslim economies where gold is a very highly sought asset having established market. The current study has investigated the impact of these two events on the gold market, and results are given below between 2008 and 2015, where the weekly averages of the gold prices are collected and utilised for analysis.

Table 2: Description of Ramazan Pre-Event, Event and Post Event Results

\begin{tabular}{|c|c|c|c|c|c|c|c|c|c|c|c|c|}
\hline $\begin{array}{c}\text { EW } \\
1\end{array}$ & Date & $\begin{array}{c}\text { Retur } \\
\text { ns }\end{array}$ & $\begin{array}{c}\mathrm{AVR} \\
\mathrm{g}\end{array}$ & $\begin{array}{c}\mathrm{ABR} \\
\mathrm{g}\end{array}$ & $\begin{array}{l}\text { AR (t } \\
\text { value) }\end{array}$ & $\begin{array}{c}\text { AR } \\
\text { sig }\end{array}$ & $\begin{array}{c}\text { CA } \\
\text { R }\end{array}$ & $\begin{array}{l}\text { CAR (t } \\
\text { value) }\end{array}$ & $\begin{array}{c}\text { CAR } \\
\text { sig }\end{array}$ & SRV & $\begin{array}{c}\text { ASR } \\
\mathbf{V}\end{array}$ & $\begin{array}{c}\text { T- } \\
\text { Value(ASRV } \\
\text { ) }\end{array}$ \\
\hline $\begin{array}{c}\text { PrR } \\
4\end{array}$ & $\begin{array}{c}17 / 08 / 0 \\
7\end{array}$ & -0.01 & 0.02 & -0.03 & -0.42 & - & $\begin{array}{c}- \\
0.03\end{array}$ & -0.42 & - & 0.231 & 0.019 & -58.131 \\
\hline $\begin{array}{c}\text { PrR } \\
3\end{array}$ & $\begin{array}{c}24 / 08 / 0 \\
7\end{array}$ & 0.00 & 0.02 & -0.02 & -0.29 & - & $\begin{array}{c}- \\
0.05\end{array}$ & -0.70 & - & 0.109 & 0.009 & -58.732 \\
\hline $\begin{array}{c}\operatorname{PrR} \\
2\end{array}$ & $\begin{array}{c}31 / 08 / 0 \\
7\end{array}$ & 0.01 & 0.02 & -0.01 & -2.08 & Sig & $\begin{array}{c}- \\
0.05\end{array}$ & -2.37 & Sig & 0.009 & 0.001 & -59.230 \\
\hline $\begin{array}{c}\operatorname{PrR} \\
1\end{array}$ & $\begin{array}{c}07 / 09 / 0 \\
7\end{array}$ & 0.03 & 0.02 & 0.02 & 2.24 & Sig & $\begin{array}{c}- \\
0.04\end{array}$ & 0.16 & - & 0.075 & 0.006 & -58.901 \\
\hline $\mathrm{R} 1$ & $\begin{array}{c}21 / 09 / 0 \\
7\end{array}$ & 0.03 & 0.02 & 0.01 & 1.08 & - & 0.01 & 3.32 & Sig & 0.009 & 0.001 & -59.230 \\
\hline R2 & $\begin{array}{c}28 / 09 / 0 \\
7\end{array}$ & 0.01 & 0.02 & -0.01 & -2.14 & Sig & 0.00 & -1.06 & - & 0.025 & 0.002 & -59.150 \\
\hline R3 & $\begin{array}{c}\text { 05-10- } \\
07\end{array}$ & 0.01 & 0.02 & -0.01 & -2.22 & Sig & $\begin{array}{c}- \\
0.02\end{array}$ & -4.37 & Sig & 0.061 & 0.005 & -58.970 \\
\hline R4 & $\begin{array}{c}12-10- \\
07\end{array}$ & 0.01 & 0.02 & -0.01 & -3.18 & Sig & $\begin{array}{c}- \\
0.03\end{array}$ & -5.40 & Sig & 0.039 & 0.003 & -59.082 \\
\hline $\begin{array}{c}\text { PoR } \\
1\end{array}$ & $\begin{array}{c}26 / 10 / 0 \\
7\end{array}$ & 0.01 & 0.00 & 0.01 & 4.06 & Sig & 0.01 & 0.88 & - & 0.019 & 0.002 & -59.180 \\
\hline $\begin{array}{c}\text { PoR } \\
2\end{array}$ & $\begin{array}{c}02 / 11 / 0 \\
7\end{array}$ & 0.04 & 0.00 & 0.04 & 3.28 & Sig & 0.05 & 7.34 & Sig & 0.409 & 0.034 & -57.254 \\
\hline $\begin{array}{c}\text { PoR } \\
3\end{array}$ & $\begin{array}{c}09 / 11 / 0 \\
7\end{array}$ & 0.04 & 0.00 & 0.05 & 2.34 & Sig & 0.09 & 5.62 & Sig & 0.626 & 0.052 & -56.180 \\
\hline $\begin{array}{c}\text { PoR } \\
4\end{array}$ & $\begin{array}{c}16 / 11 / 0 \\
7\end{array}$ & -0.03 & 0.00 & -0.03 & -0.21 & - & 0.06 & 2.13 & Sig & 0.233 & 0.019 & -58.121 \\
\hline PrR & $01 / 08 / 0$ & 0.18 & 0.02 & 0.17 & 2.45 & Sig & 0.39 & 5.72 & Sig & 8.059 & 0.672 & -19.465 \\
\hline
\end{tabular}




\begin{tabular}{|c|c|c|c|c|c|c|c|c|c|c|c|c|}
\hline 5 & 8 & & & & & & & & & & & \\
\hline $\begin{array}{c}\text { PrR } \\
4\end{array}$ & $\begin{array}{c}08 / 08 / 0 \\
8 \\
\end{array}$ & -0.03 & 0.02 & -0.05 & -0.74 & - & 0.34 & 4.98 & Sig & 0.724 & 0.060 & -55.695 \\
\hline $\begin{array}{c}\operatorname{PrR} \\
3\end{array}$ & $\begin{array}{c}15 / 08 / 0 \\
8\end{array}$ & -0.04 & 0.02 & -0.06 & -0.90 & - & 0.28 & 4.08 & Sig & 1.078 & 0.090 & -53.947 \\
\hline $\begin{array}{c}\mathrm{PrR} \\
2\end{array}$ & $\begin{array}{c}22 / 08 / 0 \\
8\end{array}$ & 0.02 & 0.02 & 0.00 & -0.02 & - & 0.27 & 4.07 & Sig & 0.000 & 0.000 & -59.271 \\
\hline $\begin{array}{c}\operatorname{PrR} \\
1\end{array}$ & $\begin{array}{c}29 / 08 / 0 \\
8\end{array}$ & 0.02 & 0.02 & 0.01 & 2.11 & Sig & 0.28 & 4.18 & Sig & 0.016 & 0.001 & -59.195 \\
\hline R1 & $\begin{array}{c}05 / 09 / 0 \\
8\end{array}$ & 0.07 & 0.02 & 0.05 & 0.73 & - & 0.25 & 3.83 & Sig & 0.639 & 0.053 & -56.115 \\
\hline R2 & $\begin{array}{c}12 / 09 / 0 \\
8 \\
\end{array}$ & -0.04 & 0.02 & -0.06 & -2.99 & Sig & 0.18 & 2.84 & Sig & 1.195 & 0.100 & -53.371 \\
\hline R3 & $\begin{array}{c}19 / 09 / 0 \\
8\end{array}$ & 0.09 & 0.02 & 0.07 & 3.07 & Sig & 0.25 & 3.91 & Sig & 1.382 & 0.115 & -52.447 \\
\hline R4 & $\begin{array}{c}26 / 09 / 0 \\
8\end{array}$ & 0.08 & 0.02 & 0.06 & 3.91 & Sig & 0.31 & 4.82 & Sig & 1.009 & 0.084 & -54.287 \\
\hline $\begin{array}{c}\text { PoR } \\
1 \\
\end{array}$ & $\begin{array}{c}03 / 10 / 0 \\
8 \\
\end{array}$ & 0.15 & 0.00 & 0.15 & 4.14 & Sig & 0.42 & 3.15 & Sig & 6.791 & 0.566 & -25.732 \\
\hline $\begin{array}{c}\text { PoR } \\
2 \\
\end{array}$ & $\begin{array}{c}10 / 10 / 0 \\
8 \\
\end{array}$ & 0.03 & 0.00 & 0.03 & 3.26 & Sig & 0.46 & 3.41 & Sig & 0.353 & 0.029 & -57.528 \\
\hline $\begin{array}{c}\text { PoR } \\
3\end{array}$ & $\begin{array}{c}17 / 10 / 0 \\
8\end{array}$ & -0.04 & 0.00 & -0.04 & -2.30 & Sig & 0.42 & 3.11 & Sig & 0.477 & 0.040 & -56.916 \\
\hline $\begin{array}{c}\text { PoR } \\
4 \\
\end{array}$ & $\begin{array}{c}24 / 10 / 0 \\
8 \\
\end{array}$ & -0.08 & 0.00 & -0.08 & -1.61 & - & 0.33 & 2.50 & Sig & 1.955 & 0.163 & -49.616 \\
\hline $\begin{array}{c}\text { PoR } \\
5\end{array}$ & $\begin{array}{c}31 / 10 / 0 \\
8 \\
\end{array}$ & -0.01 & 0.00 & -0.01 & -0.09 & - & 0.32 & 2.41 & Sig & 0.044 & 0.004 & -59.056 \\
\hline $\begin{array}{c}\text { EW } \\
1 \\
\end{array}$ & Date & $\begin{array}{c}\text { Return } \\
\mathrm{s}\end{array}$ & $\begin{array}{c}\text { AVR } \\
\mathrm{g}\end{array}$ & $\begin{array}{c}\mathrm{ABR} \\
\mathrm{g}\end{array}$ & $\begin{array}{l}\text { AR }(t \\
\text { value })\end{array}$ & $\begin{array}{l}\text { AR } \\
\text { sig }\end{array}$ & $\begin{array}{c}\mathrm{CA} \\
\mathrm{R}\end{array}$ & $\begin{array}{l}\text { CAR (t } \\
\text { value) }\end{array}$ & $\begin{array}{c}\text { CAR } \\
\text { sig } \\
\end{array}$ & SRV & $\begin{array}{c}\text { ASR } \\
\mathrm{V}\end{array}$ & $\begin{array}{c}\mathrm{T}- \\
\text { Value(ASRV) }\end{array}$ \\
\hline $\begin{array}{c}\operatorname{PrR} \\
5\end{array}$ & $\begin{array}{c}24 / 07 / 0 \\
9\end{array}$ & 0.20 & 0.02 & 0.18 & 2.68 & Sig & 0.45 & 6.60 & Sig & 9.611 & 0.801 & -11.801 \\
\hline $\begin{array}{c}\operatorname{PrR} \\
4 \\
\end{array}$ & $\begin{array}{c}31 / 07 / 0 \\
9 \\
\end{array}$ & 0.00 & 0.02 & -0.02 & -2.24 & Sig & 0.43 & 6.36 & Sig & 0.079 & 0.007 & -58.881 \\
\hline $\begin{array}{c}\text { PrR } \\
3 \\
\end{array}$ & $\begin{array}{c}07 / 08 / 0 \\
9 \\
\end{array}$ & 0.02 & 0.02 & 0.00 & 2.03 & Sig & 0.43 & 6.39 & Sig & 0.001 & 0.000 & -59.268 \\
\hline $\begin{array}{c}\operatorname{PrR} \\
2 \\
\end{array}$ & $\begin{array}{c}14 / 08 / 0 \\
9 \\
\end{array}$ & -0.02 & 0.02 & -0.03 & -0.50 & - & 0.40 & 5.89 & Sig & 0.332 & 0.028 & -57.635 \\
\hline $\begin{array}{c}\text { PrR } \\
1 \\
\end{array}$ & $\begin{array}{c}21 / 08 / 0 \\
9 \\
\end{array}$ & -0.01 & 0.02 & -0.03 & -0.39 & - & 0.37 & 5.50 & Sig & 0.200 & 0.017 & -58.285 \\
\hline R1 & $\begin{array}{c}28 / 08 / 0 \\
9\end{array}$ & 0.09 & 0.02 & 0.07 & 1.16 & - & 0.38 & 5.87 & Sig & 1.637 & 0.136 & -51.187 \\
\hline R2 & $\begin{array}{c}04 / 09 / 0 \\
9 \\
\end{array}$ & 0.03 & 0.02 & 0.01 & 0.18 & - & 0.39 & 6.06 & Sig & 0.041 & 0.003 & -59.070 \\
\hline R3 & $\begin{array}{c}11 / 09 / 0 \\
9 \\
\end{array}$ & 0.02 & 0.02 & 0.00 & 2.04 & Sig & 0.39 & 6.09 & Sig & 0.002 & 0.000 & -59.264 \\
\hline R4 & $\begin{array}{c}18 / 09 / 0 \\
9\end{array}$ & 0.01 & 0.02 & -0.01 & -2.14 & Sig & 0.38 & 5.96 & Sig & 0.022 & 0.002 & -59.163 \\
\hline $\begin{array}{c}\text { PoR } \\
1 \\
\end{array}$ & $\begin{array}{c}25 / 09 / 0 \\
9 \\
\end{array}$ & 0.10 & 0.00 & 0.11 & 2.80 & Sig & 0.68 & 5.07 & Sig & 3.362 & 0.280 & -42.668 \\
\hline $\begin{array}{c}\text { PoR } \\
2 \\
\end{array}$ & $\begin{array}{c}02 / 10 / 0 \\
9 \\
\end{array}$ & 0.00 & 0.00 & 0.00 & 3.02 & Sig & 0.68 & 5.09 & Sig & 0.002 & 0.000 & -59.264 \\
\hline $\begin{array}{c}\text { PoR } \\
3 \\
\end{array}$ & $\begin{array}{c}\text { 09/10/0 } \\
9 \\
\end{array}$ & 0.04 & 0.00 & 0.04 & 3.32 & Sig & 0.73 & 5.41 & Sig & 0.543 & 0.045 & -56.590 \\
\hline $\begin{array}{c}\text { PoR } \\
4 \\
\end{array}$ & $\begin{array}{c}16 / 10 / 0 \\
9 \\
\end{array}$ & 0.02 & 0.00 & 0.02 & 2.13 & Sig & 0.74 & 5.54 & Sig & 0.089 & 0.007 & -58.831 \\
\hline PoR & $23 / 10 / 0$ & 0.00 & 0.00 & 0.01 & 1.04 & - & 0.75 & 5.58 & Sig & 0.008 & 0.001 & -59.235 \\
\hline
\end{tabular}




\begin{tabular}{|c|c|c|c|c|c|c|c|c|c|c|c|c|}
\hline 5 & 9 & & & & & & & & & & & \\
\hline $\begin{array}{c}\operatorname{PrR} \\
5\end{array}$ & $\begin{array}{c}09 / 07 / 1 \\
0\end{array}$ & 0.11 & 0.02 & 0.10 & 1.41 & - & 0.61 & 9.10 & Sig & 1.305 & 0.072 & 47.140 \\
\hline $\begin{array}{c}\operatorname{PrR} \\
4\end{array}$ & $\begin{array}{c}16 / 07 / 1 \\
0\end{array}$ & 0.00 & 0.02 & -0.02 & -0.26 & - & 0.60 & 8.83 & Sig & 0.045 & 0.002 & 50.697 \\
\hline $\begin{array}{c}\mathrm{PrR} \\
3\end{array}$ & $\begin{array}{c}23 / 07 / 1 \\
0\end{array}$ & -0.01 & 0.02 & -0.03 & -0.44 & - & 0.57 & 8.39 & Sig & 0.129 & 0.007 & 50.458 \\
\hline $\begin{array}{c}\operatorname{PrR} \\
2\end{array}$ & $\begin{array}{c}30 / 07 / 1 \\
0\end{array}$ & -0.02 & 0.02 & -0.03 & -2.49 & Sig & 0.53 & 7.90 & Sig & 0.159 & 0.009 & 50.374 \\
\hline $\begin{array}{c}\text { PrR } \\
1\end{array}$ & $\begin{array}{c}06 / 08 / 1 \\
0\end{array}$ & 0.02 & 0.02 & 0.00 & 3.05 & Sig & 0.54 & 7.94 & Sig & 0.001 & 0.000 & 50.820 \\
\hline R1 & $\begin{array}{c}13 / 08 / 1 \\
0\end{array}$ & 0.08 & 0.02 & 0.06 & 0.98 & - & 0.55 & 8.52 & Sig & 0.568 & 0.032 & 49.220 \\
\hline R2 & $\begin{array}{c}20 / 08 / 1 \\
0\end{array}$ & 0.02 & 0.02 & 0.00 & -0.08 & - & 0.54 & 8.44 & Sig & 0.004 & 0.000 & 50.814 \\
\hline R3 & $\begin{array}{c}27 / 08 / 1 \\
0\end{array}$ & 0.00 & 0.02 & -0.02 & -2.26 & Sig & 0.53 & 8.18 & Sig & 0.040 & 0.002 & 50.712 \\
\hline R4 & $\begin{array}{c}03 / 09 / 1 \\
0\end{array}$ & 0.01 & 0.02 & -0.01 & -3.16 & Sig & 0.52 & 8.02 & Sig & 0.016 & 0.001 & 50.779 \\
\hline R5 & $\begin{array}{c}10 / 09 / 1 \\
0\end{array}$ & 0.01 & 0.02 & -0.01 & -3.19 & Sig & 0.50 & 7.83 & Sig & 0.021 & 0.001 & 50.765 \\
\hline $\begin{array}{c}\text { PoR } \\
1 \\
\end{array}$ & $\begin{array}{c}17 / 09 / 1 \\
0 \\
\end{array}$ & 0.17 & 0.00 & 0.17 & 4.30 & Sig & 0.98 & 7.33 & Sig & 4.365 & 0.243 & 38.499 \\
\hline $\begin{array}{c}\text { PoR } \\
2\end{array}$ & $\begin{array}{c}24 / 09 / 1 \\
0\end{array}$ & 0.02 & 0.00 & 0.02 & 4.15 & Sig & 1.00 & 7.48 & Sig & 0.056 & 0.003 & 50.666 \\
\hline $\begin{array}{c}\text { PoR } \\
3 \\
\end{array}$ & $\begin{array}{c}01 / 10 / 1 \\
0\end{array}$ & 0.02 & 0.00 & 0.02 & 3.18 & Sig & 1.03 & 7.65 & Sig & 0.079 & 0.004 & 50.600 \\
\hline $\begin{array}{c}\text { PoR } \\
4\end{array}$ & $\begin{array}{c}08 / 10 / 1 \\
0\end{array}$ & 0.02 & 0.00 & 0.02 & 2.16 & Sig & 1.05 & 7.82 & Sig & 0.067 & 0.004 & 50.634 \\
\hline $\begin{array}{c}\text { EW } \\
1 \\
\end{array}$ & Date & $\begin{array}{c}\text { Return } \\
\mathrm{s}\end{array}$ & $\begin{array}{c}\text { AVR } \\
\mathrm{g}\end{array}$ & $\begin{array}{c}\mathrm{ABR} \\
\mathrm{g}\end{array}$ & $\begin{array}{l}\mathrm{AR}(\mathrm{t} \\
\text { value })\end{array}$ & $\begin{array}{l}\text { AR } \\
\text { sig }\end{array}$ & $\begin{array}{c}\mathrm{CA} \\
\mathrm{R} \\
\end{array}$ & $\begin{array}{l}\text { CAR (t } \\
\text { value) }\end{array}$ & $\begin{array}{c}\text { CAR } \\
\text { sig }\end{array}$ & SRV & $\begin{array}{c}\text { ASR } \\
\mathrm{V}\end{array}$ & $\begin{array}{c}\text { T- } \\
\text { Value(ASRV) }\end{array}$ \\
\hline $\begin{array}{c}\text { PoR } \\
5\end{array}$ & $\begin{array}{c}15 / 10 / 1 \\
0\end{array}$ & 0.02 & 0.00 & 0.02 & 1.18 & - & 1.07 & 7.99 & Sig & 0.082 & 0.005 & 50.593 \\
\hline $\begin{array}{c}\operatorname{PrR} \\
5\end{array}$ & $\begin{array}{c}01 / 07 / 1 \\
1\end{array}$ & 0.08 & 0.02 & 0.07 & 0.99 & - & 0.71 & 10.54 & Sig & 0.641 & 0.036 & 49.013 \\
\hline $\begin{array}{c}\text { PrR } \\
4 \\
\end{array}$ & $\begin{array}{c}08 / 07 / 1 \\
1\end{array}$ & 0.01 & 0.02 & 0.00 & -0.06 & - & 0.71 & 10.49 & Sig & 0.002 & 0.000 & 50.818 \\
\hline $\begin{array}{c}\text { PrR } \\
3\end{array}$ & $\begin{array}{c}15 / 07 / 1 \\
1\end{array}$ & 0.03 & 0.02 & 0.02 & 0.26 & - & 0.73 & 10.74 & Sig & 0.044 & 0.002 & 50.700 \\
\hline $\begin{array}{c}\text { PrR } \\
2 \\
\end{array}$ & $\begin{array}{c}22 / 07 / 1 \\
1 \\
\end{array}$ & 0.02 & 0.02 & 0.00 & -2.03 & Sig & 0.72 & 10.72 & Sig & 0.001 & 0.000 & 50.822 \\
\hline $\begin{array}{c}\operatorname{PrR} \\
1 \\
\end{array}$ & $\begin{array}{c}29 / 07 / 1 \\
1 \\
\end{array}$ & 0.02 & 0.02 & 0.00 & 2.00 & Sig & 0.72 & 10.72 & Sig & 0.000 & 0.000 & 50.824 \\
\hline R1 & $\begin{array}{c}05 / 08 / 1 \\
1 \\
\end{array}$ & 0.21 & 0.02 & 0.19 & 2.89 & Sig & 0.76 & 11.75 & Sig & 4.971 & 0.276 & 36.788 \\
\hline R2 & $\begin{array}{c}12 / 08 / 1 \\
1\end{array}$ & 0.06 & 0.02 & 0.04 & 0.62 & - & 0.80 & 12.37 & Sig & 0.226 & 0.013 & 50.185 \\
\hline R3 & $\begin{array}{c}19 / 08 / 1 \\
1\end{array}$ & 0.03 & 0.02 & 0.01 & 0.12 & - & 0.80 & 12.49 & Sig & 0.009 & 0.000 & 50.800 \\
\hline R4 & $\begin{array}{c}26 / 08 / 1 \\
1 \\
\end{array}$ & 0.01 & 0.02 & -0.01 & -2.13 & Sig & 0.79 & 12.36 & Sig & 0.010 & 0.001 & 50.795 \\
\hline $\begin{array}{c}\text { PoR } \\
1 \\
\end{array}$ & $\begin{array}{c}02 / 09 / 1 \\
1 \\
\end{array}$ & 0.35 & 0.00 & 0.35 & 4.61 & Sig & 1.44 & 10.72 & Sig & $\begin{array}{r}17.60 \\
4\end{array}$ & 0.978 & 1.117 \\
\hline $\begin{array}{c}\text { PoR } \\
2 \\
\end{array}$ & $\begin{array}{c}09 / 09 / 1 \\
1 \\
\end{array}$ & 0.03 & 0.00 & 0.03 & 4.21 & Sig & 1.46 & 10.93 & Sig & 0.113 & 0.006 & 50.504 \\
\hline PoR & $16 / 09 / 1$ & -0.03 & 0.00 & -0.03 & -3.22 & Sig & 1.44 & 10.71 & Sig & 0.121 & 0.007 & 50.482 \\
\hline
\end{tabular}




\begin{tabular}{|c|c|c|c|c|c|c|c|c|c|c|c|c|}
\hline 3 & 1 & & & & & & & & & & & \\
\hline $\begin{array}{c}\text { PoR } \\
4\end{array}$ & $\begin{array}{c}23 / 09 / 1 \\
1\end{array}$ & -0.03 & 0.00 & -0.03 & -2.23 & Sig & 1.40 & 10.48 & Sig & 0.139 & 0.008 & 50.432 \\
\hline $\begin{array}{c}\text { PoR } \\
5\end{array}$ & $\begin{array}{c}30 / 09 / 1 \\
1\end{array}$ & -0.08 & 0.00 & -0.08 & -1.58 & - & 1.33 & 9.90 & Sig & 0.861 & 0.048 & 48.393 \\
\hline $\begin{array}{c}\operatorname{PrR} \\
5\end{array}$ & $\begin{array}{c}15 / 06 / 1 \\
2\end{array}$ & 0.03 & 0.02 & 0.01 & 3.18 & Sig & 0.75 & 11.02 & Sig & 0.020 & 0.001 & 50.766 \\
\hline $\begin{array}{c}\operatorname{PrR} \\
4\end{array}$ & $\begin{array}{c}22 / 06 / 1 \\
2\end{array}$ & -0.01 & 0.02 & -0.03 & -3.45 & Sig & 0.71 & 10.57 & Sig & 0.131 & 0.007 & 50.453 \\
\hline $\begin{array}{c}\text { PrR } \\
3\end{array}$ & $\begin{array}{c}29 / 06 / 1 \\
2\end{array}$ & -0.01 & 0.02 & -0.03 & -0.41 & - & 0.69 & 10.16 & Sig & 0.113 & 0.006 & 50.505 \\
\hline $\begin{array}{c}\text { PrR } \\
2 \\
\end{array}$ & $\begin{array}{c}06 / 07 / 1 \\
2\end{array}$ & 0.02 & 0.02 & 0.00 & 0.02 & - & 0.69 & 10.18 & Sig & 0.000 & 0.000 & 50.823 \\
\hline $\begin{array}{c}\operatorname{PrR} \\
1\end{array}$ & $\begin{array}{c}13 / 07 / 1 \\
2\end{array}$ & -0.02 & 0.02 & -0.04 & -0.54 & - & 0.65 & 9.64 & Sig & 0.191 & 0.011 & 50.286 \\
\hline R1 & $\begin{array}{c}20 / 07 / 1 \\
2\end{array}$ & -0.03 & 0.02 & -0.05 & -0.74 & - & 0.68 & 10.58 & Sig & 0.329 & 0.018 & 49.896 \\
\hline R2 & $\begin{array}{c}27 / 07 / 1 \\
2\end{array}$ & 0.02 & 0.02 & 0.00 & -0.07 & - & 0.68 & 10.50 & Sig & 0.003 & 0.000 & 50.815 \\
\hline R3 & $\begin{array}{c}03 / 08 / 1 \\
2\end{array}$ & 0.00 & 0.02 & -0.02 & -0.29 & - & 0.66 & 10.21 & Sig & 0.050 & 0.003 & 50.682 \\
\hline R4 & $\begin{array}{c}10 / 08 / 1 \\
2 \\
\end{array}$ & 0.00 & 0.02 & -0.02 & -2.32 & Sig & 0.64 & 9.89 & Sig & 0.061 & 0.003 & 50.650 \\
\hline R5 & $\begin{array}{c}17 / 08 / 1 \\
2\end{array}$ & 0.00 & 0.02 & -0.02 & -3.35 & Sig & 0.61 & 9.54 & Sig & 0.071 & 0.004 & 50.622 \\
\hline $\begin{array}{c}\text { PoR } \\
1 \\
\end{array}$ & $\begin{array}{c}24 / 08 / 1 \\
2 \\
\end{array}$ & 0.09 & 0.00 & 0.09 & 4.70 & Sig & 1.43 & 10.64 & Sig & 1.254 & 0.070 & 47.284 \\
\hline $\begin{array}{c}\text { PoR } \\
2\end{array}$ & $\begin{array}{c}31 / 08 / 1 \\
2\end{array}$ & 0.01 & 0.00 & 0.01 & 4.06 & Sig & 1.43 & 10.70 & Sig & 0.008 & 0.000 & 50.800 \\
\hline $\begin{array}{c}\text { PoR } \\
3\end{array}$ & $\begin{array}{c}07 / 09 / 1 \\
2\end{array}$ & 0.01 & 0.00 & 0.02 & 3.12 & Sig & 1.45 & 10.82 & Sig & 0.036 & 0.002 & 50.722 \\
\hline $\begin{array}{c}\text { EW } \\
1 \\
\end{array}$ & Date & $\begin{array}{c}\text { Return } \\
\mathrm{s}\end{array}$ & $\begin{array}{c}\text { AVR } \\
\mathrm{g}\end{array}$ & $\begin{array}{c}\text { ABR } \\
\mathrm{g}\end{array}$ & $\begin{array}{l}\text { AR }(\mathrm{t} \\
\text { value })\end{array}$ & $\begin{array}{l}\text { AR } \\
\text { sig }\end{array}$ & $\begin{array}{c}\mathrm{CA} \\
\mathrm{R}\end{array}$ & $\begin{array}{l}\text { CAR (t } \\
\text { value) }\end{array}$ & $\begin{array}{c}\text { CAR } \\
\text { sig }\end{array}$ & SRV & $\begin{array}{c}\text { ASR } \\
\mathrm{V}\end{array}$ & $\begin{array}{c}\text { T- } \\
\text { Value(ASRV) }\end{array}$ \\
\hline $\begin{array}{c}\text { PoR } \\
4\end{array}$ & $\begin{array}{c}14 / 09 / 1 \\
2\end{array}$ & 0.03 & 0.00 & 0.04 & 2.26 & Sig & 1.49 & 11.08 & Sig & 0.178 & 0.010 & 50.321 \\
\hline $\begin{array}{c}\text { PoR } \\
5\end{array}$ & $\begin{array}{c}21 / 09 / 1 \\
2\end{array}$ & 0.03 & 0.00 & 0.03 & 0.24 & - & 1.52 & 11.32 & Sig & 0.152 & 0.008 & 50.394 \\
\hline $\begin{array}{c}\operatorname{PrR} \\
5\end{array}$ & $\begin{array}{c}07 / 06 / 1 \\
3 \\
\end{array}$ & -0.17 & 0.02 & -0.19 & -2.80 & Sig & 0.52 & 7.64 & Sig & 5.126 & 0.285 & 36.352 \\
\hline $\begin{array}{c}\text { PrR } \\
4 \\
\end{array}$ & $\begin{array}{c}14 / 06 / 1 \\
3 \\
\end{array}$ & 0.00 & 0.02 & -0.02 & -0.25 & - & 0.50 & 7.39 & Sig & 0.041 & 0.002 & 50.709 \\
\hline $\begin{array}{c}\operatorname{PrR} \\
3 \\
\end{array}$ & $\begin{array}{c}21 / 06 / 1 \\
3 \\
\end{array}$ & -0.03 & 0.02 & -0.05 & -0.77 & - & 0.45 & 6.61 & Sig & 0.391 & 0.022 & 49.718 \\
\hline $\begin{array}{c}\text { PrR } \\
2 \\
\end{array}$ & $\begin{array}{c}28 / 06 / 1 \\
3 \\
\end{array}$ & -0.06 & 0.02 & -0.08 & -1.21 & - & 0.37 & 5.40 & Sig & 0.962 & 0.053 & 48.107 \\
\hline $\begin{array}{c}\text { PrR } \\
1\end{array}$ & $\begin{array}{c}05 / 07 / 1 \\
3\end{array}$ & 0.01 & 0.02 & -0.01 & -0.11 & - & 0.36 & 5.29 & Sig & 0.008 & 0.000 & 50.801 \\
\hline $\mathrm{R} 1$ & $\begin{array}{c}12 / 07 / 1 \\
3 \\
\end{array}$ & -0.24 & 0.02 & -0.26 & -4.09 & Sig & 0.41 & 6.36 & Sig & 9.952 & 0.553 & 22.724 \\
\hline R2 & $\begin{array}{c}19 / 07 / 1 \\
3 \\
\end{array}$ & 0.02 & 0.02 & 0.00 & 0.06 & - & 0.41 & 6.42 & Sig & 0.002 & 0.000 & 50.817 \\
\hline R3 & $\begin{array}{c}26 / 07 / 1 \\
3 \\
\end{array}$ & 0.04 & 0.02 & 0.02 & 0.35 & - & 0.44 & 6.77 & Sig & 0.071 & 0.004 & 50.622 \\
\hline $\mathrm{R} 4$ & $\begin{array}{c}02 / 08 / 1 \\
3 \\
\end{array}$ & 0.00 & 0.02 & -0.02 & -3.34 & Sig & 0.41 & 6.43 & Sig & 0.069 & 0.004 & 50.630 \\
\hline PoR & $09 / 08 / 1$ & -0.20 & 0.00 & -0.20 & -5.47 & Sig & 1.32 & 9.84 & Sig & 5.582 & 0.310 & 35.062 \\
\hline
\end{tabular}




\begin{tabular}{|c|c|c|c|c|c|c|c|c|c|c|c|c|}
\hline 1 & 3 & & & & & & & & & & & \\
\hline $\begin{array}{c}\text { PoR } \\
2\end{array}$ & $\begin{array}{c}16 / 08 / 1 \\
3\end{array}$ & 0.04 & 0.00 & 0.04 & 4.33 & Sig & 1.36 & 10.17 & Sig & 0.278 & 0.015 & 50.039 \\
\hline $\begin{array}{c}\text { PoR } \\
3 \\
\end{array}$ & $\begin{array}{c}23 / 08 / 1 \\
3 \\
\end{array}$ & 0.03 & 0.00 & 0.03 & 3.22 & Sig & 1.39 & 10.39 & Sig & 0.124 & 0.007 & 50.474 \\
\hline $\begin{array}{c}\text { PoR } \\
4\end{array}$ & $\begin{array}{c}30 / 08 / 1 \\
3\end{array}$ & 0.03 & 0.00 & 0.03 & 0.25 & - & 1.43 & 10.64 & Sig & 0.156 & 0.009 & 50.384 \\
\hline $\begin{array}{c}\text { PoR } \\
5 \\
\end{array}$ & $\begin{array}{c}06 / 09 / 1 \\
3 \\
\end{array}$ & -0.01 & 0.00 & 0.00 & -0.03 & - & 1.42 & 10.61 & Sig & 0.003 & 0.000 & 50.817 \\
\hline $\begin{array}{c}\text { PrR } \\
5 \\
\end{array}$ & $\begin{array}{c}23 / 05 / 1 \\
4 \\
\end{array}$ & -0.10 & 0.02 & -0.12 & -1.78 & - & 0.33 & 4.81 & Sig & $\begin{array}{r}15.34 \\
8 \\
\end{array}$ & 1.535 & 54.949 \\
\hline $\begin{array}{c}\text { PrR } \\
4\end{array}$ & $\begin{array}{c}30 / 05 / 1 \\
4\end{array}$ & -0.02 & 0.02 & -0.04 & -0.60 & - & 0.28 & 4.20 & Sig & 1.764 & 0.176 & -84.626 \\
\hline $\begin{array}{c}\text { PrR } \\
3 \\
\end{array}$ & $\begin{array}{c}06 / 06 / 1 \\
4 \\
\end{array}$ & -0.01 & 0.02 & -0.03 & -0.47 & - & 0.25 & 3.73 & Sig & 1.075 & 0.107 & -91.710 \\
\hline $\begin{array}{c}\text { PrR } \\
2 \\
\end{array}$ & $\begin{array}{c}13 / 06 / 1 \\
4\end{array}$ & 0.01 & 0.02 & 0.00 & -0.05 & - & 0.25 & 3.68 & Sig & 0.014 & 0.001 & -102.613 \\
\hline $\begin{array}{c}\text { PrR } \\
1\end{array}$ & $\begin{array}{c}20 / 06 / 1 \\
4\end{array}$ & 0.02 & 0.02 & 0.00 & 0.04 & - & 0.25 & 3.71 & Sig & 0.007 & 0.001 & -102.684 \\
\hline R1 & $\begin{array}{c}27 / 06 / 1 \\
4 \\
\end{array}$ & -0.05 & 0.02 & -0.08 & -1.17 & - & 0.32 & 5.00 & Sig & 5.963 & 0.596 & -41.480 \\
\hline $\mathrm{R} 2$ & $\begin{array}{c}04 / 07 / 1 \\
4 \\
\end{array}$ & 0.01 & 0.02 & -0.01 & -0.23 & - & 0.31 & 4.77 & Sig & 0.227 & 0.023 & -100.421 \\
\hline $\mathrm{R} 3$ & $\begin{array}{c}11 / 07 / 1 \\
4 \\
\end{array}$ & 0.00 & 0.02 & -0.02 & -0.26 & - & 0.29 & 4.51 & Sig & 0.299 & 0.030 & -99.680 \\
\hline $\mathrm{R} 4$ & $\begin{array}{c}18 / 07 / 1 \\
4\end{array}$ & -0.02 & 0.02 & -0.04 & -0.56 & - & 0.25 & 3.95 & Sig & 1.363 & 0.136 & -88.750 \\
\hline R5 & $\begin{array}{c}25 / 07 / 1 \\
4 \\
\end{array}$ & 0.00 & 0.02 & -0.02 & -3.33 & Sig & 0.23 & 3.62 & Sig & 0.484 & 0.048 & -97.77 \\
\hline $\begin{array}{c}\text { PoR } \\
1 \\
\end{array}$ & $\begin{array}{c}01 / 08 / 1 \\
4 \\
\end{array}$ & -0.04 & 0.00 & -0.04 & -6.29 & Sig & 1.30 & 9.73 & Sig & 1.558 & 0.156 & -86.743 \\
\hline $\begin{array}{c}\text { PoR } \\
2 \\
\end{array}$ & $\begin{array}{c}08 / 08 / 1 \\
4 \\
\end{array}$ & 0.01 & 0.00 & 0.01 & 5.06 & Sig & 1.31 & 9.79 & Sig & 0.065 & 0.006 & -102.08 \\
\hline $\begin{array}{c}\text { EW } \\
1\end{array}$ & Date & $\begin{array}{c}\text { Retur } \\
\text { ns }\end{array}$ & $\begin{array}{c}\mathbf{A V R} \\
\mathbf{g}\end{array}$ & $\begin{array}{c}\mathbf{A B R} \\
\mathbf{g}\end{array}$ & $\begin{array}{l}\text { AR (t } \\
\text { value) }\end{array}$ & $\begin{array}{c}\text { AR } \\
\text { sig }\end{array}$ & $\begin{array}{c}\text { CA } \\
\mathbf{R}\end{array}$ & $\begin{array}{l}\text { CAR (t } \\
\text { value) }\end{array}$ & $\begin{array}{c}\text { CAR } \\
\text { sig }\end{array}$ & SRV & $\begin{array}{c}\text { ASR } \\
\mathbf{V}\end{array}$ & $\begin{array}{c}\text { T- } \\
\text { Value(ASRV } \\
\text { ) }\end{array}$ \\
\hline $\begin{array}{c}\text { PoR } \\
3 \\
\end{array}$ & $\begin{array}{c}15 / 08 / 1 \\
4\end{array}$ & 0.01 & 0.00 & 0.01 & 4.09 & Sig & 1.32 & 9.88 & Sig & 0.165 & 0.017 & -101.05 \\
\hline $\begin{array}{c}\text { PoR } \\
4 \\
\end{array}$ & $\begin{array}{c}22 / 08 / 1 \\
4 \\
\end{array}$ & 0.00 & 0.00 & 0.00 & 0.00 & - & 1.32 & 9.88 & Sig & 0.000 & 0.000 & -102.75 \\
\hline $\begin{array}{c}\text { PoR } \\
5\end{array}$ & $\begin{array}{c}29 / 08 / 1 \\
4\end{array}$ & 0.01 & 0.00 & 0.01 & 0.05 & - & 1.33 & 9.93 & Sig & 0.055 & 0.005 & -102.19 \\
\hline $\begin{array}{c}\operatorname{PrR} \\
5 \\
\end{array}$ & $\begin{array}{c}15 / 05 / 1 \\
5 \\
\end{array}$ & -0.04 & 0.02 & -0.05 & -3.80 & Sig & 0.15 & 2.22 & Sig & 3.072 & 0.307 & -71.190 \\
\hline $\begin{array}{c}\operatorname{PrR} \\
4 \\
\end{array}$ & $\begin{array}{c}22 / 05 / 1 \\
5 \\
\end{array}$ & 0.00 & 0.02 & -0.01 & -2.21 & Sig & 0.14 & 2.01 & Sig & 0.213 & 0.021 & -100.56 \\
\hline $\begin{array}{c}\text { PrR } \\
3\end{array}$ & $\begin{array}{c}29 / 05 / 1 \\
5\end{array}$ & -0.02 & 0.02 & -0.03 & -2.49 & Sig & 0.10 & 1.52 & - & 1.142 & 0.114 & -91.021 \\
\hline $\begin{array}{c}\operatorname{PrR} \\
2 \\
\end{array}$ & $\begin{array}{c}05 / 06 / 1 \\
5 \\
\end{array}$ & -0.01 & 0.02 & -0.03 & -0.37 & - & 0.08 & 1.15 & - & 0.662 & 0.066 & -95.955 \\
\hline $\begin{array}{c}\text { PrR } \\
1 \\
\end{array}$ & $\begin{array}{c}12 / 06 / 1 \\
5 \\
\end{array}$ & 0.00 & 0.02 & -0.02 & -0.31 & - & 0.06 & 0.85 & - & 0.455 & 0.045 & -98.085 \\
\hline $\mathrm{R} 1$ & $\begin{array}{c}19 / 06 / 1 \\
5 \\
\end{array}$ & 0.02 & 0.02 & 0.00 & -0.04 & - & 0.11 & 1.77 & - & 0.007 & 0.001 & -102.67 \\
\hline $\mathrm{R} 2$ & $\begin{array}{c}26 / 06 / 1 \\
5 \\
\end{array}$ & -0.01 & 0.02 & -0.03 & -0.51 & - & 0.08 & 1.25 & - & 1.144 & 0.114 & -90.999 \\
\hline
\end{tabular}




\begin{tabular}{ccccccccccccc}
\hline R3 & $\begin{array}{c}03 / 07 / 1 \\
5\end{array}$ & 0.00 & 0.02 & -0.02 & -0.39 & - & 0.06 & 0.87 & - & 0.651 & 0.065 & -96.062 \\
\hline R4 & $\begin{array}{c}10 / 07 / 1 \\
5\end{array}$ & -0.01 & 0.02 & -0.03 & -0.45 & - & 0.03 & 0.41 & - & 0.899 & 0.090 & -93.517 \\
& & & & & & & & & & & & \\
\hline R5 & $\begin{array}{c}17 / 07 / 1 \\
5\end{array}$ & -0.01 & 0.02 & -0.03 & -3.47 & Sig & 0.00 & -0.06 & - & 0.980 & 0.098 & -92.683 \\
\hline $\begin{array}{c}\text { PoR } \\
14 / 07 / 1\end{array}$ & -0.08 & 0.00 & -0.07 & -6.56 & Sig & 1.19 & 8.91 & Sig & 5.856 & 0.586 & -42.585 \\
\hline $\begin{array}{c}\text { PoR } \\
2\end{array}$ & $\begin{array}{c}31 / 07 / 1 \\
5\end{array}$ & 0.00 & 0.00 & 0.00 & -5.00 & Sig & 1.19 & 8.91 & Sig & 0.000 & 0.000 & -102.75 \\
\hline $\begin{array}{c}\text { PoR } \\
3\end{array}$ & $\begin{array}{c}07 / 08 / 1 \\
5\end{array}$ & -0.01 & 0.00 & 0.00 & -4.03 & Sig & 1.19 & 8.88 & Sig & 0.014 & 0.001 & -102.61 \\
\hline $\begin{array}{c}\text { PoR } \\
4\end{array}$ & $\begin{array}{c}14 / 08 / 1 \\
5\end{array}$ & 0.02 & 0.00 & 0.03 & 3.19 & Sig & 1.22 & 9.07 & Sig & 0.662 & 0.066 & -95.952 \\
\hline $\begin{array}{c}\text { PoR } \\
5\end{array}$ & $\begin{array}{c}21 / 08 / 1 \\
5\end{array}$ & 0.02 & 0.00 & 0.02 & 0.17 & - & 1.24 & 9.23 & Sig & 0.522 & 0.052 & -97.387 \\
\hline
\end{tabular}

\section{Analysis for Ramazan (pre-event, event, and post-event effect)}

Abnormal returns were calculated by taking the difference of the gold returns with the average return, and the trace test was applied to capture significance by applying conditions on results. In the second stage, CAR methodology was applied to measure significant abnormal returns to determine that significant returns are either result of the market anomaly. Later average security return variability is calculated to capture the magnitude of reaction during, before, and after the events.

Table 2 shows the summary of tests results applied to analyse the Ramazan Effect; a mixed trend can be seen in the preevent window, and a similar trend is detected in various years. Insignificant behaviour of gold returns was detected in the first 2-3 weeks of a pre-event window during 2007, 2010 \& 2011. Near and at the arrival of Ramazan, gold returns generated significant abnormal returns that are reconfirmed by the CAR and ASRV results, and this finding rejects the hypothesis of semi-strong form efficiency in the gold market for the pre-event window. The insignificant behaviour of gold returns was there in $3^{\text {td }}, 4^{\text {th, }}$ and $5^{\text {th }}$ weeks for years $2008 \& 2013$, but again in 2008 , one week before Ramazan returns become significant, i.e., abnormal returns in 2013 returns were significant in the initial few weeks indicating the presence of abnormal return and semi-strong form inefficiencies in the gold market thus again refuting hypothesis.

Pre-event weeks of 2009, 2012 \& 2015 were found significant; however, the last 2 weeks for the same year had insignificant returns, whereas complete 2014 was found insignificant because no abnormal return was there in the pre-event window. Hence with the exception of only 2014, the significant abnormal reaction can be observed in all the gold returns. This behaviour indicates significant influence and interaction of demand and supply forces before the arrival of Ramazan events every year. These findings refute the efficiency hypothesis in the gold market during the Ramazan pre window, and the existence of abnormal returns shows that the gold market is semi-strong-form inefficient. Since CAR and ASRV methodology was employed to determine how accurate the model is. More often, it is used to investigate the effect of superfluous events on asset prices. Here, both analyses provided evidence of abnormal returns of the gold not due to market anomaly but due to Ramazan. The significant value for abnormal return in Ramazan pre-event is captured in the year 2012, which is 0.19 with a t-value of 2.80 , showing the negative absorption of Ramazan in the pre-event period.

Similarly, another evidence of abnormal return with the highest t-value of 3.45 is captured in 2012, which positively absorbs Ramazan's arrival. The table analysis shows that overall the gold market has reacted consistently to the Ramazan event arrival. Therefore it can be assessed that Ramazan event arrival has an impact on the gold prices. In short, it can be concluded that the gold prices properly reacted to Ramazan and thus fail to support the semi-strong form of the gold market efficiency.

During the event, mixed behaviour can be seen, somewhere reaction is there and somewhere not captured. However, CAR and ASRV results also reconfirm the presence of significant abnormal returns during the event, therefore, refuting the hypothesis. A similar normal pattern can also be detected during the first two weeks in 2009-10, but in later weeks of an event, significantly abnormal returns are generated again, leading to the hypothesis's refusal upon combined CARs, ASRV \& Trace stats. Insignificant return behaviour is captured during mid-term events in $2011 \& 2013$, whereas abnormal returns were detected at the beginning and end of the event. The gold returns are insignificant during the first three weeks of events during 2012, 2014-15 but again displayed abnormal returns by the end of the event, i.e., Ramazan month. Therefore, leading to the notion that after generating abnormal returns in later weeks of pre-period, their restoration to equilibrium begins at the start of Ramazan, and returns increase with the passage of events turning into abnormal returns. This behaviour of the gold market indicated that in the gold market, demand and supply forces are highly affected by Ramazan every year. Results 
became significant except for the initial few days. This typical behaviour may get repeated as in Pakistan wedding season is at its peak after Ramazan (Nadeem, Zakarya \& Kayyani, 2014). These findings fail to support EMH in the gold market for Ramazan.

In the case of the post-event window, last weeks during 2007, through 2015 (whole sample period), insignificant return behaviour is captured, whereas significant behaviour is captured in weeks that passed right after Ramazan. CARs \& ASRV values reconfirm significant returns in immediate post-Ramazan weeks, thereby nullifying the hypothesis of semi-strong form efficiency in the gold market. This significant behaviour of the gold market in the post-event window indicated that in the gold market, demand and supply forces are highly influenced by Ramazan's occurrence repeatedly every year. This behaviour may get repeated as in Pakistan wedding season is at its peak after Ramazan (Nadeem, Zakarya \& Kayyani, 2014).

It can be concluded from the above analysis that the month of Ramazan generates a mixed reaction in the gold market returns in the pre-event, event, and post-event period, and inefficiencies prevail in the gold market in the context of this Islamic calendar anomaly.

\section{Muharram/Aashura Event Analysis \& Results (pre, event, and post effect)}

Similar to Ramazan, the gold market behaviour is analysed during the Aashoura event, and a sample period of nine years' data based on a weekly average price of the gold traded during 2008-2015 is taken. Abnormal returns are calculated by subtracting the average returns of the gold from weekly returns. In the next step trace test is applied to capture the significance by applying conditions on results. After that, CARs, ASRVs, and their respective $t$-values are calculated for measuring significant returns to determine whether abnormal returns resulted from some market anomaly of Aashura.

Table 3 display the results of Aashura event analysis for pre, post and event window, and the pre-event window depict results unlike Ramazan pre window but almost similar sort of impact situation. Far before Muharram's arrival, the gold returns show significant returns in the beginning, but near arrival, the gold returns show a decreasing trend indicating negative impact yielded by the effective event. This trend in the gold returns is consistently observed almost every year, and similar behaviour repeatedly prevails in every sample year. This behaviour is also inconsistent with EMH for the event of Aashura. Furthermore, CAR \& ASRV methodology is taken up to determine model accuracy due to its popularity in investigating the effect of extraneous events on asset prices. Significant returns from CAR for all years except 2015 confirm that abnormal returns are caused by the event arrival and not due to some market anomaly. Another evidence for abnormal returns in a per-event window can be seen in 2010, with the highest t- value depicting positive absorption. This behaviour of the gold market indicated that demand and supply forces, interaction is affected by Aashoura events every year as results are significant and follow a similar pattern. The findings are inconsistent with the efficiency hypothesis for the gold market for Aashoura pre-event.

Table 3: Description of Muharram Pre-event, Event and Post-event Results

\begin{tabular}{|c|c|c|c|c|c|c|c|c|c|c|c|c|}
\hline $\begin{array}{c}\text { EW } \\
1\end{array}$ & Date & $\begin{array}{c}\text { Retu } \\
\text { rn }\end{array}$ & $\begin{array}{l}\text { Average } \\
\text { Return }\end{array}$ & $\begin{array}{c}\text { Abnormal } \\
\text { Return }\end{array}$ & $\begin{array}{l}\text { AR t } \\
\text { stat }\end{array}$ & $\begin{array}{l}\text { AR } \\
\text { sig }\end{array}$ & $\begin{array}{c}\text { CA } \\
\mathbf{R}\end{array}$ & $\begin{array}{c}\text { CAR t } \\
\text { test }\end{array}$ & $\begin{array}{c}\text { CAR } \\
\text { sig }\end{array}$ & SRV & $\begin{array}{c}\text { ASR } \\
\mathbf{V}\end{array}$ & $\begin{array}{c}\text { T- } \\
\text { Value(ASR } \\
\text { V) }\end{array}$ \\
\hline $\begin{array}{c}\text { PrAs } \\
3\end{array}$ & $\begin{array}{c}04 / 01 / \\
08\end{array}$ & 0.26 & 0.02 & 0.25 & 3.64 & Sig & 0.21 & 3.10 & Sig & 8.232 & 1.029 & 0.954 \\
\hline $\begin{array}{c}\text { PrAs } \\
2\end{array}$ & $\begin{array}{c}11 / 01 / \\
08\end{array}$ & 0.04 & 0.02 & 0.02 & 0.28 & - & 0.23 & 3.38 & Sig & 0.047 & 0.006 & -32.741 \\
\hline $\begin{array}{c}\text { PrAs } \\
1\end{array}$ & $\begin{array}{c}18 / 01 / \\
08\end{array}$ & 0.01 & 0.02 & -0.01 & -0.11 & - & 0.22 & 3.26 & Sig & 0.008 & 0.001 & -32.903 \\
\hline M1 & $\begin{array}{c}25 / 01 / \\
08\end{array}$ & 0.24 & 0.02 & 0.22 & 1.37 & - & 0.19 & 2.91 & Sig & 6.373 & 0.797 & -6.696 \\
\hline M2 & $\begin{array}{c}01 / 02 / \\
08\end{array}$ & 0.03 & 0.02 & 0.01 & 0.20 & - & 0.20 & 3.11 & Sig & 0.022 & 0.003 & -32.843 \\
\hline $\begin{array}{c}\text { PoA } \\
\text { s1 }\end{array}$ & $\begin{array}{c}08 / 02 / \\
08\end{array}$ & 0.17 & 0.00 & 0.17 & 1.26 & - & 0.23 & 1.73 & - & 3.841 & 0.480 & -17.123 \\
\hline $\begin{array}{c}\text { PoA } \\
\text { s2 }\end{array}$ & $\begin{array}{c}15 / 02 / \\
08\end{array}$ & 0.01 & 0.00 & 0.01 & 1.07 & - & 0.24 & 1.80 & - & 0.013 & 0.002 & -32.880 \\
\hline $\begin{array}{c}\text { PoA } \\
\text { s3 }\end{array}$ & $\begin{array}{c}22 / 02 / \\
08\end{array}$ & 0.03 & 0.00 & 0.03 & 1.21 & - & 0.27 & 2.01 & Sig & 0.108 & 0.014 & -32.489 \\
\hline $\begin{array}{c}\text { PrAs } \\
3\end{array}$ & $\begin{array}{c}02 / 01 / \\
09\end{array}$ & 0.09 & 0.02 & 0.08 & 2.12 & Sig & 0.36 & 5.29 & Sig & 0.774 & 0.097 & -29.750 \\
\hline PrAs & $09 / 01 /$ & -0.03 & 0.02 & -0.05 & -0.75 & - & 0.31 & 4.54 & Sig & 0.35 & 0.044 & -31.486 \\
\hline
\end{tabular}



https://doi.org/10.18510/hssr.2021.9230

\begin{tabular}{|c|c|c|c|c|c|c|c|c|c|c|c|}
\hline 2 & 09 & & & & & & & & & & \\
\hline $\begin{array}{c}\text { PrAs } \\
1\end{array}$ & $\begin{array}{c}16 / 01 / \\
09\end{array}$ & -0.02 & 0.02 & -0.04 & -0.62 & - & 0.27 & 3.92 & Sig & 0.2360 .029 & -31.963 \\
\hline M1 & $\begin{array}{c}23 / 01 / \\
09\end{array}$ & -0.01 & 0.02 & -0.03 & -0.50 & - & 0.28 & 4.32 & Sig & 0.1400 .018 & -32.358 \\
\hline M2 & $\begin{array}{c}30 / 01 / \\
09\end{array}$ & 0.05 & 0.02 & 0.02 & 0.39 & - & 0.30 & 4.71 & Sig & 0.0840 .011 & -32.588 \\
\hline $\begin{array}{c}\text { PoA } \\
\text { s1 }\end{array}$ & $\begin{array}{c}06 / 03 / \\
09\end{array}$ & 0.23 & 0.00 & 0.23 & 1.70 & - & 0.55 & 4.11 & Sig & $\begin{array}{lll}7.051 & 0.881\end{array}$ & -3.909 \\
\hline $\begin{array}{c}\text { PoA } \\
\text { s2 }\end{array}$ & $\begin{array}{c}13 / 03 / \\
09\end{array}$ & -0.01 & 0.00 & 0.00 & -0.04 & - & 0.55 & 4.07 & Sig & 0.0030 .000 & -32.922 \\
\hline $\begin{array}{c}\mathrm{PoA} \\
\mathrm{s} 3\end{array}$ & $\begin{array}{c}20 / 03 / \\
09\end{array}$ & 0.02 & 0.00 & 0.03 & 2.20 & Sig & 0.57 & 4.27 & Sig & 0.0970 .012 & -32.534 \\
\hline $\begin{array}{l}\text { PrAs } \\
3\end{array}$ & $\begin{array}{c}11 / 12 / \\
09\end{array}$ & 0.23 & 0.02 & 0.22 & 3.19 & Sig & 0.59 & 8.69 & Sig & 6.2910 .786 & -7.036 \\
\hline $\begin{array}{l}\text { PrAs } \\
2\end{array}$ & $\begin{array}{c}18 / 12 / \\
09\end{array}$ & -0.01 & 0.02 & -0.03 & -0.44 & - & 0.56 & 8.25 & Sig & 0.1180 .015 & -32.450 \\
\hline $\begin{array}{c}\text { PrAs } \\
1\end{array}$ & $\begin{array}{c}25 / 12 / \\
09\end{array}$ & -0.02 & 0.02 & -0.04 & -0.57 & - & 0.52 & 7.69 & Sig & 0.1990 .025 & -32.116 \\
\hline M1 & $\begin{array}{c}01 / 01 / \\
10\end{array}$ & 0.11 & 0.02 & 0.09 & 1.38 & - & 0.47 & 7.34 & Sig & 1.0640 .133 & -28.553 \\
\hline M2 & $\begin{array}{c}08 / 01 / \\
10\end{array}$ & 0.03 & 0.02 & 0.01 & 0.21 & - & 0.49 & 7.54 & Sig & 0.0240 .003 & -32.837 \\
\hline $\begin{array}{c}\text { PoA } \\
\text { s1 }\end{array}$ & $\begin{array}{c}15 / 01 / \\
10\end{array}$ & 0.09 & 0.00 & 0.10 & 0.71 & - & 0.84 & 6.29 & Sig & 1.2320 .154 & -27.862 \\
\hline $\begin{array}{c}\mathrm{PoA} \\
\text { s2 }\end{array}$ & $\begin{array}{c}22 / 01 / \\
10\end{array}$ & -0.02 & 0.00 & -0.02 & -0.15 & - & 0.82 & 6.14 & Sig & 0.0510 .006 & -32.723 \\
\hline $\begin{array}{c}\text { PoA } \\
\text { s3 }\end{array}$ & $\begin{array}{c}29 / 01 / \\
10\end{array}$ & -0.02 & 0.00 & -0.02 & -2.11 & Sig & 0.81 & 6.03 & Sig & 0.0310 .004 & -32.807 \\
\hline $\begin{array}{c}\text { PrAs } \\
3\end{array}$ & $\begin{array}{c}19 / 11 / \\
10\end{array}$ & 0.13 & 0.02 & 0.11 & 4.67 & Sig & 0.65 & 9.61 & Sig & 1.7230 .215 & -25.840 \\
\hline $\begin{array}{c}\text { PrAs } \\
2\end{array}$ & $\begin{array}{c}26 / 11 / \\
10\end{array}$ & 0.01 & 0.02 & 0.00 & -0.04 & - & 0.65 & 9.58 & Sig & 0.0010 .000 & -32.931 \\
\hline $\begin{array}{c}\text { PrAs } \\
1\end{array}$ & $\begin{array}{c}03 / 12 / \\
10\end{array}$ & 0.02 & 0.02 & 0.00 & -0.02 & - & 0.65 & 9.55 & Sig & 0.0000 .000 & -32.934 \\
\hline $\begin{array}{c}\text { EW } \\
1\end{array}$ & Date & $\begin{array}{c}\text { Retur } \\
\mathrm{n}\end{array}$ & $\begin{array}{l}\text { Average } \\
\text { Return }\end{array}$ & $\begin{array}{l}\text { Abnormal } \\
\text { Return }\end{array}$ & $\begin{array}{c}\text { AR t } \\
\text { stat }\end{array}$ & $\begin{array}{l}\text { AR } \\
\text { sig }\end{array}$ & $\begin{array}{c}\mathrm{CA} \\
\mathrm{R}\end{array}$ & $\begin{array}{l}\text { CAR t } \\
\text { test }\end{array}$ & $\begin{array}{c}\text { CAR } \\
\text { sig }\end{array}$ & $\begin{array}{c}\text { SRV ASR } \\
\text { V }\end{array}$ & $\begin{array}{c}\mathrm{T}- \\
\text { Value(ASR } \\
\text { V) }\end{array}$ \\
\hline M1 & $\begin{array}{c}10 / 12 / \\
10\end{array}$ & 0.11 & 0.02 & 0.09 & 1.47 & - & 0.60 & 9.30 & Sig & 1.2110 .151 & -27.950 \\
\hline M2 & $\begin{array}{c}17 / 12 / \\
10\end{array}$ & -0.01 & 0.02 & -0.03 & -0.45 & - & 0.57 & 8.86 & Sig & 0.1110 .014 & -32.477 \\
\hline $\begin{array}{c}\text { PoA } \\
\text { s1 }\end{array}$ & $\begin{array}{c}24 / 12 / \\
10\end{array}$ & 0.01 & 0.00 & 0.01 & 0.09 & - & 1.08 & 8.08 & Sig & 0.0180 .002 & -32.860 \\
\hline $\begin{array}{c}\mathrm{PoA} \\
\text { s2 }\end{array}$ & $\begin{array}{c}31 / 12 / \\
10\end{array}$ & 0.02 & 0.00 & 0.02 & 0.13 & - & 1.10 & 8.21 & Sig & 0.0440 .006 & -32.753 \\
\hline $\begin{array}{c}\text { PoA } \\
\text { s3 }\end{array}$ & $\begin{array}{c}07 / 01 / \\
11\end{array}$ & -0.02 & 0.00 & -0.01 & -0.11 & - & 1.09 & 8.10 & Sig & 0.0300 .004 & -32.812 \\
\hline $\begin{array}{c}\text { PrAs } \\
3\end{array}$ & $\begin{array}{c}10 / 11 / \\
11\end{array}$ & 0.09 & 0.02 & 0.07 & 3.02 & Sig & 0.79 & 11.73 & Sig & 0.2140 .021 & -20.833 \\
\hline $\begin{array}{c}\text { PrAs } \\
2\end{array}$ & $\begin{array}{c}18 / 11 / \\
11\end{array}$ & 0.00 & 0.02 & -0.01 & -0.19 & - & 0.78 & 11.55 & Sig & $\begin{array}{lll}0.007 & 0.001\end{array}$ & -21.272 \\
\hline $\begin{array}{c}\text { PrAs } \\
1\end{array}$ & $\begin{array}{c}25 / 11 / \\
11\end{array}$ & -0.03 & 0.02 & -0.05 & -0.70 & - & 0.73 & 10.84 & Sig & 0.1020 .010 & -21.070 \\
\hline M1 & $\begin{array}{c}02 / 12 / \\
11 \\
\end{array}$ & -0.03 & 0.02 & -0.05 & -0.78 & - & 0.74 & 11.58 & Sig & 0.1130 .011 & -21.047 \\
\hline
\end{tabular}


elSSN: 2395-6518, Vol 9, No 2, 2021, pp 293-313 https://doi.org/10.18510/hssr.2021.9230

\begin{tabular}{|c|c|c|c|c|c|c|c|c|c|c|c|}
\hline M2 & $\begin{array}{c}09 / 12 / \\
11\end{array}$ & 0.00 & 0.02 & -0.02 & -0.26 & - & 0.73 & 11.32 & Sig & 0.0130 .001 & -21.261 \\
\hline $\begin{array}{c}\text { PoA } \\
\text { s1 }\end{array}$ & $\begin{array}{c}16 / 12 / \\
11\end{array}$ & 0.02 & 0.00 & 0.02 & 0.13 & - & 1.34 & 10.03 & Sig & 0.0140 .001 & -21.258 \\
\hline $\begin{array}{l}\text { PoA } \\
\text { s2 }\end{array}$ & $\begin{array}{c}23 / 12 / \\
11\end{array}$ & 0.01 & 0.00 & 0.01 & 0.06 & - & 1.35 & 10.09 & Sig & 0.0030 .000 & -21.283 \\
\hline $\begin{array}{c}\text { PoA } \\
\text { s3 }\end{array}$ & $\begin{array}{c}30 / 12 / \\
11\end{array}$ & -0.02 & 0.00 & -0.02 & -0.14 & - & 1.33 & 9.94 & Sig & 0.0160 .002 & -21.253 \\
\hline $\begin{array}{l}\text { PrAs } \\
3\end{array}$ & $\begin{array}{c}26 / 10 / \\
12\end{array}$ & 0.10 & 0.02 & 0.08 & 3.22 & Sig & 0.73 & 10.86 & Sig & $0.308 \quad 0.031$ & -20.633 \\
\hline $\begin{array}{l}\text { PrAs } \\
2\end{array}$ & $\begin{array}{c}02 / 11 / \\
12\end{array}$ & 0.00 & 0.02 & -0.02 & -0.29 & - & 0.71 & 10.57 & Sig & 0.0170 .002 & -21.251 \\
\hline $\begin{array}{c}\text { PrAs } \\
1\end{array}$ & $\begin{array}{c}09 / 11 / \\
12\end{array}$ & 0.01 & 0.02 & -0.01 & -0.14 & - & 0.71 & 10.43 & Sig & 0.0040 .000 & -21.280 \\
\hline M1 & $\begin{array}{c}16 / 11 / \\
12\end{array}$ & 0.09 & 0.02 & 0.07 & 1.09 & - & 0.68 & 10.63 & Sig & 0.2220 .022 & -20.815 \\
\hline M2 & $\begin{array}{c}23 / 11 / \\
12\end{array}$ & 0.01 & 0.02 & -0.01 & -0.18 & - & 0.67 & 10.45 & Sig & 0.0060 .001 & -21.275 \\
\hline $\begin{array}{c}\text { PoA } \\
\text { s1 }\end{array}$ & $\begin{array}{c}30 / 11 / \\
12\end{array}$ & 0.00 & 0.00 & 0.00 & -0.01 & - & 1.52 & 11.31 & Sig & $\begin{array}{lll}0.000 & 0.000\end{array}$ & -21.288 \\
\hline $\begin{array}{c}\text { PoA } \\
\text { s2 }\end{array}$ & $\begin{array}{c}07 / 12 / \\
12\end{array}$ & -0.01 & 0.00 & -0.01 & -0.08 & - & 1.51 & 11.23 & Sig & 0.0050 .001 & -21.276 \\
\hline $\begin{array}{c}\text { PoA } \\
\text { s3 }\end{array}$ & $\begin{array}{c}14 / 12 / \\
12 \\
\end{array}$ & 0.01 & 0.00 & 0.01 & 0.08 & - & 1.52 & 11.32 & Sig & 0.0060 .001 & -21.276 \\
\hline $\begin{array}{c}\text { PrAs } \\
3\end{array}$ & $\begin{array}{c}18 / 10 / \\
13\end{array}$ & 0.10 & 0.02 & 0.08 & 3.25 & Sig & 0.44 & 6.54 & Sig & 0.3230 .032 & -20.601 \\
\hline $\begin{array}{c}\text { PrAs } \\
2\end{array}$ & $\begin{array}{c}25 / 10 / \\
13\end{array}$ & 0.04 & 0.02 & 0.02 & 0.29 & - & 0.46 & 6.83 & Sig & 0.0180 .002 & -21.250 \\
\hline $\begin{array}{c}\text { PrAs } \\
1 \\
\end{array}$ & $\begin{array}{c}01 / 11 / \\
13\end{array}$ & 0.00 & 0.02 & -0.02 & -0.24 & - & 0.45 & 6.59 & Sig & 0.0120 .001 & -21.262 \\
\hline M1 & $\begin{array}{c}08 / 11 / \\
13\end{array}$ & 0.04 & 0.02 & 0.02 & 0.35 & - & 0.44 & 6.77 & Sig & 0.0230 .002 & -21.240 \\
\hline M2 & $\begin{array}{c}15 / 11 / \\
13\end{array}$ & -0.02 & 0.02 & -0.04 & -0.61 & - & 0.40 & 6.17 & Sig & 0.0690 .007 & -21.141 \\
\hline $\begin{array}{c}\text { PoA } \\
\text { s1 }\end{array}$ & $\begin{array}{c}22 / 11 / \\
13\end{array}$ & -0.07 & 0.00 & -0.07 & -0.53 & - & 1.35 & 10.08 & Sig & 0.2250 .022 & -20.810 \\
\hline $\begin{array}{c}\text { PoA } \\
\text { s2 } \\
\end{array}$ & $\begin{array}{c}29 / 11 / \\
13 \\
\end{array}$ & 0.00 & 0.00 & 0.00 & 0.00 & - & 1.35 & 10.08 & Sig & 0.0000 .000 & -21.288 \\
\hline $\begin{array}{c}\text { PoA } \\
\text { s3 }\end{array}$ & $\begin{array}{c}06 / 12 / \\
13\end{array}$ & -0.01 & 0.00 & -0.01 & -0.07 & - & 1.34 & 10.01 & Sig & 0.0040 .000 & -21.280 \\
\hline $\begin{array}{c}\text { EW } \\
1\end{array}$ & Date & $\begin{array}{c}\text { Retur } \\
\mathrm{n}\end{array}$ & $\begin{array}{l}\text { Average } \\
\text { Return }\end{array}$ & $\begin{array}{l}\text { Abnormal } \\
\text { Return }\end{array}$ & $\begin{array}{l}\text { AR t } \\
\text { stat }\end{array}$ & $\begin{array}{l}\text { AR } \\
\text { sig }\end{array}$ & $\begin{array}{c}\text { CA } \\
\mathrm{R}\end{array}$ & $\begin{array}{l}\text { CAR t } \\
\text { test }\end{array}$ & $\begin{array}{c}\text { CAR } \\
\text { sig }\end{array}$ & $\begin{array}{c}\text { SRV ASR } \\
\text { V }\end{array}$ & $\begin{array}{c}\text { T- } \\
\text { Value(ASR } \\
\text { V) }\end{array}$ \\
\hline $\begin{array}{c}\text { PrAs } \\
3 \\
\end{array}$ & $\begin{array}{c}10 / 10 / \\
14\end{array}$ & -0.02 & 0.02 & -0.04 & -2.55 & Sig & 0.21 & 3.16 & Sig & 0.0630 .006 & -21.153 \\
\hline $\begin{array}{l}\text { PrAs } \\
2 \\
\end{array}$ & $\begin{array}{c}17 / 10 / \\
14\end{array}$ & 0.02 & 0.02 & 0.00 & -0.01 & - & 0.21 & 3.15 & Sig & $\begin{array}{lll}0.000 & 0.000\end{array}$ & -21.288 \\
\hline $\begin{array}{c}\text { PrAs } \\
1 \\
\end{array}$ & $\begin{array}{c}24 / 10 / \\
14\end{array}$ & 0.01 & 0.02 & -0.01 & -0.14 & - & 0.20 & 3.02 & Sig & 0.0040 .000 & -21.280 \\
\hline M1 & $\begin{array}{c}31 / 10 / \\
14\end{array}$ & -0.03 & 0.02 & -0.05 & -0.85 & - & 0.18 & 2.77 & Sig & 0.1340 .013 & -21.002 \\
\hline M2 & $\begin{array}{c}07 / 11 / \\
14\end{array}$ & -0.04 & 0.02 & -0.06 & -0.96 & - & 0.12 & 1.81 & - & $0.174 \quad 0.017$ & -20.918 \\
\hline $\begin{array}{c}\text { PoA } \\
\text { s1 }\end{array}$ & $\begin{array}{c}14 / 11 / \\
14\end{array}$ & -0.09 & 0.00 & -0.09 & -0.66 & - & 1.24 & 9.28 & Sig & 0.3510 .035 & -20.542 \\
\hline PoA & $21 / 11 /$ & 0.02 & 0.00 & 0.03 & 0.19 & - & 1.27 & 9.47 & Sig & 0.0290 .003 & -21.226 \\
\hline
\end{tabular}




\begin{tabular}{|c|c|c|c|c|c|c|c|c|c|c|c|}
\hline s2 & 14 & & & & & & & & & & \\
\hline $\begin{array}{c}\text { PoA } \\
\text { s3 }\end{array}$ & $\begin{array}{c}28 / 11 / \\
14\end{array}$ & 0.00 & 0.00 & 0.00 & 0.00 & - & 1.27 & 9.46 & Sig & 0.0000 .000 & -21.288 \\
\hline $\begin{array}{c}\text { PrAs } \\
3\end{array}$ & $\begin{array}{c}25 / 09 / \\
15\end{array}$ & -0.01 & 0.02 & -0.03 & -2.43 & Sig & 0.03 & 0.42 & - & 0.0370 .004 & -21.208 \\
\hline $\begin{array}{c}\text { PrAs } \\
2\end{array}$ & $\begin{array}{c}02 / 10 / \\
15\end{array}$ & -0.01 & 0.02 & -0.03 & -0.42 & - & 0.00 & 0.00 & - & 0.0370 .004 & -21.210 \\
\hline $\begin{array}{c}\text { PrAs } \\
1 \\
\end{array}$ & $\begin{array}{c}09 / 10 / \\
15 \\
\end{array}$ & 0.02 & 0.02 & 0.00 & 0.00 & - & 0.00 & 0.00 & - & $\begin{array}{lll}0.000 & 0.000\end{array}$ & -21.288 \\
\hline M1 & $\begin{array}{c}16 / 10 / \\
15\end{array}$ & 0.05 & 0.02 & 0.03 & 0.46 & - & 0.03 & 0.40 & - & $0.040 \quad 0.004$ & -21.203 \\
\hline M2 & $\begin{array}{c}23 / 10 / \\
15\end{array}$ & -0.01 & 0.02 & -0.03 & -0.40 & - & 0.00 & 0.00 & - & 0.0300 .003 & -21.223 \\
\hline $\begin{array}{c}\text { PoA } \\
\text { s1 }\end{array}$ & $\begin{array}{c}30 / 10 / \\
15\end{array}$ & -0.80 & 0.00 & -0.80 & -5.99 & Sig & 0.44 & 3.25 & Sig & $\begin{array}{c}29.182 .919 \\
9\end{array}$ & 40.850 \\
\hline $\begin{array}{c}\text { PoA } \\
\text { s2 }\end{array}$ & $\begin{array}{c}06 / 11 / \\
15\end{array}$ & -0.46 & 0.00 & -0.46 & -3.43 & Sig & $\begin{array}{c}- \\
0.02\end{array}$ & -0.18 & - & 9.5980 .960 & -0.856 \\
\hline $\begin{array}{c}\text { PoA } \\
\text { s3 }\end{array}$ & $\begin{array}{c}13 / 11 / \\
15\end{array}$ & 0.02 & 0.00 & 0.02 & 0.18 & - & 0.00 & 0.00 & - & 0.0280 .003 & -21.229 \\
\hline
\end{tabular}

The Aashura event window in Table 3 shows that the same behavior prevails throughout the sample period every year. Furthermore, insignificant behaviour of the gold returns that started from the first week of pre window even sustained event window for all years, and no abnormal returns were generated during the event in any year. This behaviour is inclined towards the hypothesis's sustenance and in favour of semi-strong form efficiency in the gold market during this particular Islamic calendar event. Furthermore, CARs \& ASRV values supported this finding and confirmed that the Aashura event did not generate any impact on the gold returns and insignificant the gold returns are the contribution of this event instead of some market anomaly.

Altogether, the post-event window displayed a different pattern where initial two weeks' insignificant returns for almost all sample years except 2008-09 indicate the prevalence of semi-strong form efficiency in the gold market in the post-event period. CAR \& ASRV values also contributed towards the same findings and confirmed no impact of Aashura on the gold returns during post-event, thus supporting the efficiency hypothesis for all sample years except 2008-09.

\section{CONCLUSION}

Gold is one of the most precious discovery that has fascinated the human kind since its discovery. It is also a highly liquid asset and is considered ideal for holding portfolio investments by sophisticated as well as non-sophisticated investors. Another world-wide use of gold is its acceptability as medium of international transactions as it is the symbol of financial stability because the countries having globally accepted currency have backed their currency by the large gold reserves possessed by them. The gold prices respond to few of the Islamic event in countries like Pakistan due to few financial decisions e.g. Zakat (wealth purification) payment during or before Ramazan and non-conduction of marriages during Muharram due to religious affiliations and respect of the sacred religious personalities. It is concluded from the above analysis, findings, and discussion that both Islamic months, i.e., Ramazan and Muharram, as per lunar cycle had a different impact on the gold market, one failed to support the hypothesis. In contrast, the influence of Muharram's first ten days supported the semi-strong form of efficiency in the gold market. The event study methodology is a very important statistical approach and is highly useful in behavioural finance studies based on secondary (time series) data. The current study found an effect of religious events on the gold market of Pakistan as the gold market exhibited the semi-strong form inefficient behaviour for the month of Ramazan but opposite for the month of Muharrum. This dissertation's findings are consistent with Ississ (2010) for Ramazan event positive absorption and refute his result of negative absorption of Ashoura event as in current findings. Ashoura event exerts no influence, and no abnormal return generation is observed.

The findings in the case of both the Islamic months clearly indicate the positive perspective of a collective rationalisation. Here, the Muslims group is ignoring such type of decision reconsideration warning that can put their religious belief and religious group affiliation at stakes. This collective rationalisation saves them from their religious group isolation.

\section{LIMITATIONS AND FUTURE RESEARCH}

This study can be further extended to testing the weak-form efficiency and strong-form efficiency of the gold market. This market can also be tested for other Islamic/religious events/months as well, e.g., religious events like Zil-Hajj, Eids, etc., for testing the gold market price behaviour and semi-strong form efficiency. The government imposed bans on importing gold at 
various times in the past, which caused variation in data for the current study. These quotas and bans have a significant impact and influence prices and supply in the gold market, so that can also be an event to investigate the semi-strong form efficiency of the gold market in Pakistan.

\section{ACKNOWLEDGEMENT}

We would like to thank all the independent reviewers of HSSR who conducted a feasibility study of our research work.

\section{AUTHORS CONTRIBUTION}

Taqadus Bashir and Misbah Wadood wrote the research paper and designed this paper's organisation; Ammara Mujtaba, Hira Idrees, Ammara Toqeer, and Ayesha Furrukh perform the statistical analysis, interpretations, and technical parts. Thus, all authors contributed significantly to this research.

\section{REFERENCES}

1. Aggarwal, R. \& L. Sonen (1988). The Nature and Efficiency of the Gold Market. Journal of Portfolio Management, 14(3), 18-21. https://doi.org/10.3905/jpm.1988.409152

2. Ahmad, M. U., \& Mahmood, A., (2009). Zakat Fund-Concept and Perspective. International Journal of Monetary Economics and Finance. 2(3/4): 197-205 https://doi.org/10.1504/IJMEF.2009.029058

3. Ahmed, K., (June 2020). Gold Hits All-Time High in Pakistan as Coronavirus Drives Investors to Safe Haven. Arab News. https://arab.news/z53ha, https://www.arabnews.pk/node/1694351/pakistan.

4. Ahsan, A. F. M. M., Chowdhury, M.A.R., \& Sarkar, A. H. (2014). An Empirical Study on Market Reaction Around the Bonus Issues Announcements in Bangladesh. Int Journal of Economics and Finance. 6 (1): 82-94. https://doi.org/10.5539/ijef.v6n1p82

5. Akhter A, Sandhu A, Butt S (2015). Islamic Calendar Effect on Market Risk and Return Evidence from Islamic Countries. Journal of Business \& Financial Affairs 4: 140. https://doi.org/10.4172/2167-0234.1000140

6. Al-Ississ, M. (2010) The Impact of Religious Experience on Financial Markets. Harvard Kennedy School of Government, Doctoral Students Mailboxes, 79 John F. Kennedy Street, Cambridge,

7. Azimi, J., Adin, M. M., Torkamanzadeh, H., \& Farahdoust, M. B. (2012). The effect of Muharram and Safar Months on Stock Return in Listed Firms on Tehran Stock Exchange. Interdisciplinary Journal of Contemporary Research in Business, 4 (7), 762-768.

8. Baber, P., Baber, R., \& Thomas, G. (2013). Factors Affecting Gold Prices; A Case Study of India. Presented at National Conference on Evolving Paradigms in Manufacturing and Service Sectors, Madhya Pradesh, India.

9. Bacheliers, L. (1900). Theory of Speculation: The Origin of Modern Finance. Francia: Gauthier-Villars.

10. Bashir, T., Ahmad, M., Ilyas, M., \& Malik, U. (2011) Weak-Form Efficiency of Textile Sector: An Empirical Evidence from Pakistan. Interdisciplinary journal of contemporary research in business. 2(12): 600-611.

11. Bashir, T., Ilyas, M., \& Furrukh, A. (2011). Testing Weak-Form Efficiency of Pakistani Stock Markets-An Empirical Study in banking sector. European Journal of Economics, Finance \& Administrative Sciences. Issue 31: 160-175.

12. Bhatia, A., Dempster, N., \& Stanley, G. M. (2011). Liquidity in the Global Gold Market. World Gold Council. 10 Old Bailey, London EC4M 7NG, United Kingdom.

13. Białkowski, J., Etebari, A., \& Wisniewski T. (2012). Fast Profits: Investor Sentiments and Stock Returns During Ramadan. Journal of banking \& Finance. 36 (3): 835-845. https://doi.org/10.1016/j.jbankfin.2011.09.014

14. Bloom, B. (2011). Applications of event study methodology to lodging stock performance. Graduate Theses and Dissertations. 11930.

15. Booth, G. G., \& Kaen, F. R. (1979). Gold and Silver Spot Prices and Market Information Efficiency. Financial Review, 14(1): 21-26. https://doi.org/10.1111/j.1540-6288.1979.tb01743.x

16. Chappell, D., \& Dowd, K. (1997) A Simple Model of the Gold Standard. Journal of Money, Credit and Banking, 29, 94-105. https://doi.org/10.2307/2953688

17. Ciner, C. (2011) Commodity Prices and Inflation: Testing in the Frequency Domain. Research in International Business and Finance, 25, 229-237. https://doi.org/10.1016/j.ribaf.2011.02.001

18. Davis, D. (2007). The Future of Gold: Price Forecast. Credit Suisee Securities Research. Economic Research Centre of the University of Western Australia, Perth, Australia.

19. Fama, E. (1965). The behavior of stock market prices. Journal of Business, 38, 34-105. https://doi.org/10.1086/294743

20. Fama, E. (1970). Efficient capital markets: A review of theory and empirical work. Journal of Finance, 25, pp. 383417. https://doi.org/10.2307/2325486

21. Fama, E. (1998). Market Efficiency, Long-Term Returns and Behavioral Finance. Journal of Financial Economics. 49 (3): 283-306. https://doi.org/10.1016/S0304-405X(98)00026-9 
22. Gold Core (2013). A Comprehensive Guide to the Gold Price. Retrieved from https://cdn2.hubspot.net/hub/233034 /file-381572308-pdf/Ebook_PDF_Uploads_2013/A-Comprehensive-Guide-to-the-Gold-Price(1).pdf

23. Grossman, S. J., \& Stiglitz, J. E. (1980). On the Impossibility of Informationally Efficient Markets. The American Economic Review. Pp 393-408.

24. Husain, F (1998). A Seasonality in the Pakistani Equity Market: The Ramadhan. Effect, Pakistan Development Review, 37, pp 77-81. https://doi.org/10.30541/v37i1pp.77-81

25. Iqbal, M. S., Khan, R. \& Ahmed, M. (2013). Conventional and Islamic anomalies in Karachi Stock Exchange. Sci. Int. Lahore, vol. 25(4), pp. 999-1007.

26. Jacobs, B. and Levy, K., (1988). Calendar Anomalies: Abnormal Returns at Calendar Turning Points. Financial Analysts Journal, 44(6), pp. 28-39. https://doi.org/10.2469/faj.v44.n6.28

27. Kendall, M. (1953). The Analysis of Economic Time Series, Part I: Prices. Journal of the Royal Statistical Society, 116(1), 11-25. https://doi.org/10.2307/2980947

28. Konchitchki \& O'Leary, (2011) Event study methodologies in information systems research. International Journal of Accounting Information Systems, 12(2), 99-115. https://doi.org/10.1016/j.accinf.2011.01.002

29. Levin, E., \& Wright, R. (2006) Short-run and Long-run Determinants of the Price of Gold. World Gold Council, Research Study No. 32.

30. Mackinlay, C. (1997) Event Studies in Finance and Economics. Journal of Economic Literature, 35(1), 13-39.

31. Mahdavi, S., \& Zhou, S. (1997) Gold and Commodity Prices as Leading Indicators of Inflation: Tests of Long-run Relationship and Predictive Performance. Journal of Economics and Business, 49, 475-489. https://doi.org/10.1016/S0148-6195(97)00034-9

32. Majeed, U., Reheman, A., Sohail, K., Bhatti, G. A., Zulfiqar, B. (2015). Islamic Calendar Events and Stock Market Reaction: Evidence from Pakistan. Science International, 27(3): 2559-2567.

33. Masroom, M. N., Yunus, W. M. A. W. M., \& Huda, M. (2020). Understanding of Significance of Zakat (Islamic Charity) for Psychological Well-Being. Journal of Critical review, 7(2): 693-697. https://doi.org/10.31838/jcr.07.02.127

34. McWilliams, A., \& Siegel, D. (1997). Events studies in management research: Theoretical and empirical issues. Academy of Management Journal, 40(3), 568-592.

35. Montier, J. (2010). The Little Book of Behavioral Investing: How Not to be Your Own Worst Enemy. Hoboken, NJ: John Wiley \& Sons. https://doi.org/10.5465/257056

36. Moore, G. (1990) Gold Prices and a Leading Index of Inflation. Challenge, 33, 52-56. https://doi.org/10.1080/05775132.1990.11471444

37. Nadeem, W., Zakarya, M., \& Kayyani, F. N. (2015) Impact of Macroeconomic Factors upon Gold Prices in Pakistan. Pakistan Journal of Social Sciences. 34(1), 383-395.

38. Ntim, C. G., English, J., Nwachukwu, J. \& Wang, Y.(2015). On the efficiency of the global gold markets. International Review of Financial Analysis, 41, 218-236. https://doi.org/10.1016/j.irfa.2015.03.013

39. O'Callaghan, M. G. (1991). The Structure and Operation of the World Gold Market. IMF Working Papers 1991/120, International Monetary Fund. https://doi.org/10.5089/9781451939590.001

40. Ranson, D., Wainright, H.C. (2005). Why Gold, Not Oil, is The Superior Predictor of Inflation, Gold Report. World Gold Council. Retrieved from https://www.gold.org/goldhub/research/why-gold-not-oil-superior-predictor-inflation

41. Schoenberg, E. (2011). Why is Gold Valuable? Nature, Social Power and the Value of Things. Cultural Geographies. SAGE Publications, Inc. 18(1): 3-24. https://doi.org/10.1177/1474474010377549

42. Seyyed, F. J. \& Abraham, A., \& Al-Hajji, M. (2005). Seasonality in stock returns and volatility: The Ramadan effect. Research in International Business and Finance, Elsevier, 19(3): 374-383. https://doi.org/10.1016/j.ribaf.2004.12.010

43. Shah, S. A. H. (2018). Strategy for Mineral Sector Development in Pakistan. Planning Commission of Pakistan, Ministry of Planning, Development \& Reform Policy, 33, 118-124.

44. Sherman, E. (1986). Gold Investment: Theory and Application. Prentice Hall.

45. Smith, G. (2002) Tests of the random walk hypothesis for London gold prices. Applied Economics Letters, 9(10), 671-674. https://doi.org/10.1080/1350485021012458

46. Thaler, R. H. (1987). Anomalies: The January Effect. Journal of Economic Perspectives, 1 (1): 197-201. https://doi.org/10.1257/jep.1.1.197

47. Thaler, R. H. (1987). Anomalies: Weekend, Holiday, Turn of the Month, and Intraday Effects. Journal of Economic Perspectives, 1 (2), 169-177. https://doi.org/10.1257/jep.1.2.169

48. Tripathy, N., \& Tripathy, A. (2016). A Study on Dynamic Relationship Between Gold Price and Stock Market Price in India. European Journal of Economics, Finance and Administrative Sciences. Issue 88, 1-17.

49. Tschoegl, A.E. (1980) Efficiency in the gold market - A note. Journal of Banking \& Finance, 4, 371-379. 
50. Wang, K.M. and Y.M. Lee (2011) The Yen for Gold, Resources Policy 36 (1), 39-48. https://doi.org/10.1016/03784266(80)90015-1

51. Wang, Wei, \& Wu, C. (2011) Analysis of the Efficiency and Multifractality of gold markets based on multifractal trended fluctuation analysis. Physica A, 390, 817-827. https://doi.org/10.1016/j.physa.2010.11.002

52. Weber, M., (1930) The Protestant Ethic and the Spirit of Capitalism. (New York: Scribner's).

53. Williams, J.B. (1938) The Theory of Investment Value. Harvard University Press, Cambridge, MA. 1997 reprint, Fraser Publishing.

54. Wright, W., Bower, G., (1992) Mood Effects On Subjective Probability Assessment. Organisational Behavior and Human Decision Processes, 52, pp. 276-291. https://doi.org/10.1016/0749-5978(92)90039-A

55. Yousef, I., \& Shehadeh, E. (2020). The Impact of COVID-19 on Gold Price Volatility. International Journal of Economics and Business Administration. 8 (4), 353-364. https://doi.org/10.35808/ijeba/592 